\title{
Growth factor-driven mechanisms associated with resistance to estrogen deprivation in breast cancer: new opportunities for therapy
}

\author{
R I Nicholson, C Staka, F Boyns, I R Hutcheson and J M W Gee
}

Tenovus Centre for Cancer Research, Welsh School of Pharmacy, Cardiff University, Cardiff, UK

(Requests for offprints should be addressed to R I Nicholson; nicholsonri@ cardiff.ac.uk)

\begin{abstract}
There is an increasing body of evidence demonstrating that elevated growth signaling in breast cancer cells can promote forms of endocrine resistance in either an estrogen receptor-dependent or -independent manner. The current article reviews what is known about such growth factor signaling networks and resistance to estrogen withdrawal and considers the many novel therapeutic opportunities that stem from this knowledge.
\end{abstract}

Endocrine-Related Cancer (2004) 11 623-641

\section{Introduction}

Within the last 5 years, clinical interest in estrogen deprivation strategies for the therapy of breast cancer has gained considerable momentum. Estrogen deprivation is achieved clinically through the use of ovarian ablation or suppression (e.g. luteinizing hormone-releasing hormone superagonists) in premenopausal women, and through aromatase inhibitors in postmenopausal women (Johnston \& Dowsett 2003, Pritchard 2003). The 'third generation aromatase inhibitors' (AIs), exemplified by the nonsteroidal competitive inhibitors of aromatase, anastrazole and letrozole, and the steroidal aromatase inactivator, exemestane, are potent and highly selective in their inhibition of the cytochrome P450 enzyme, aromatase. As a consequence, they efficiently block conversion of androgens (testosterone and androstenedione) to estrogens (estradiol and estrone respectively) in peripheral tissues and breast tumors (Santen 2003). Their induction of profound estrogen deprivation provides an effective therapeutic second line strategy in advanced postmenopausal estrogen receptor positive $(\mathrm{ER} \alpha+)$ breast cancer (Johnston \& Dowsett 2003). Moreover, emerging trial data indicate that AIs may be superior to the antiestrogen tamoxifen both as first line agents in advanced ER $\alpha+$ patients and in the adjuvant setting (reviewed by Santen 2003). Thus, letrozole, anastrozole and exemestane have all achieved an increased tumor response rate in advanced disease, while in the ongoing ATAC (Anastrozole, Tamoxifen, Alone or in Combination) trial in early breast cancer, a significant improvement in 3-year disease-free survival with a reduced incidence of contralateral invasive breast cancers has been reported for anastrozole compared with tamoxifen (Baum et al. 2003, Wong \& Ellis 2004). Clearly, longer follow-up for AI adjuvant trials such as ATAC remains essential if we are to judiciously assess whether these agents could be of routine value in the postmenopausal adjuvant setting (Winer et al. 2003). However, the clinical data are encouraging to date and there is hope that AIs may, in the future, replace tamoxifen as the 'gold standard' therapy for ER $\alpha+$ disease and perhaps further improve breast cancer survival rates (Santen 2003). Our emerging knowledge of the molecular biology of $\mathrm{ER} \alpha$ signaling sheds light on these promising observations. While the AF-2 activity of $\mathrm{ER} \alpha$ is silenced, it is notable that weak AF-1-mediated agonistic effects are retained following tamoxifen binding to $\mathrm{ER} \alpha$. In contrast, under conditions of near-complete estrogen deprivation, it is predicted that $\mathrm{ER} \alpha$ activity and hence $\mathrm{ER} \alpha$-mediated transcription would be fully abrogated (Johnston \& Dowsett 2003).

Clearly, exciting advances in the endocrine therapy of breast cancer continue to be made. Importantly, however, as promising as the above prospects are, it is already 
evident that a switch to estrogen deprivation as the preferred endocrine strategy will not provide the whole answer to effective treatment of breast cancer. Thus, to date, improvement in relapse-free survival in the adjuvant setting observed with AIs versus tamoxifen remains modest. Moreover, not all patients who are treated with AIs respond equally well, while relapse rates in advanced disease are still unfortunately often measured in months rather than years (Pritchard 2003). So where should we look for the next advance in the therapy of breast cancer? Clearly, accurate identification of the causative elements for primary (de novo) and acquired endocrine resistance is essential if we are to develop new therapeutic approaches to delay, prevent or potentially even reverse these undesirable conditions (Nicholson et al. 2003). The biology of endocrine resistance is highly complex and poorly understood. As such, diverse mechanisms have been implicated that are at various stages of experimentation and exploitation. Several groups have focussed on whether alterations occurring in the structure/function of $\mathrm{ER} \alpha$ contribute to resistance. For example, studies by Fuqua et al. (2000) demonstrate that ER $\alpha$ mutation (Lys303Arg) enables increased co-activator recruitment to the receptor, conferring hypersensitivity in the presence of reduced estrogens. Moreover, in some model systems, aromatase is increased in response to estrogen deprivation in parallel with acquisition of estrogen hypersensitivity, while aromatase-transfected MCF-7 cells are also hypersensitive (Yue et al. 2001, 2003). However, the role of such events in invasive breast cancer and clinical endocrine resistance remains obscure (Karnick et al. 1994, de Jong et al. 2003). In contrast, there is considerable evidence that growth factor signaling pathways should be of high priority in our quest for new therapeutic targets in endocrine resistance (Nicholson et al. 2003). Thus, the current article reviews the growth factor signaling-driven mechanisms that have been implicated to date in resistance to estrogen withdrawal primarily from breast cancer model systems. Where possible, parallels will be drawn with resistance to antiestrogens. Based on these concepts, the article will suggest how we might in the future effectively and rationally target growth factor signaling pathways to enhance response to estrogen deprivation and improve breast cancer survival.

\section{Growth factor signaling associates with resistance to endocrine therapies, including estrogen deprivation}

Developing breast cancer cells are bathed in a rich milieu of peptide growth factors that are produced locally or distally. Additionally, many neoplastic cells are able to produce growth factors by autocrine means and frequently express several classes of growth factor receptors and their downstream signaling elements (Salomon et al. 1995, Nicholson et al. 2001b, Sachdev \& Yee 2001, Gross \& Yee 2003). Cancer cell responses to growth factors include enhancement of proliferation, cell survival, motility, invasiveness and angiogenesis (Wells 1999, Ciardiello \& Tortora 2001, Sachdev \& Yee 2001, Gross \& Yee 2003). Thus, it is not surprising that inappropriate activation of growth factor signaling cascades, either through the enhanced supply of growth factor ligands or via up-regulation/increased activation of their target receptors or their recruited downstream signaling elements can associate with aggressive tumor biology and poor patient prognosis (Ciardiello \& Tortora 2001, Nicholson et al. 2001a, 2004). Moreover, there is now considerable evidence that increased signaling through such pathways promotes in vitro/in vivo resistance to various cytotoxics (Dickstein et al. 1995, Gooch et al. 1999, Chen et al. 2000), radiotherapy (Dunn et al. 1997, Akimoto et al. 1999, Gee \& Nicholson 2003), and notably endocrine strategies in breast cancer cells (Nicholson et al. 1994, 2004).

As an example, increased epidermal growth factor (EGF) receptor (EGFR) signaling is a relatively common feature in established cell models that have become refractory to antiestrogens (Vickers et al. 1988, Long et al. 1992, van Agthoven et al. 1994, van den Berg et al. 1996, McClelland et al. 2001, Knowlden et al. 2003b). Thus, our established MCF-7, and more recently T47D, human breast cancer sub-lines that have acquired resistance to tamoxifen or fulvestrant in vitro clearly demonstrate dominance of EGFR/HER2 signaling, with increased activation of the downstream growth factor signaling elements erk1/2 MAP kinase and Akt that are pivotal in driving antiestrogen resistant growth (McClelland et al. 2001, Knowlden et al. 2003b, Jordan et al. 2004). Extensive gene transfer studies further highlight the considerable potential for increased expression/activation of growth factor pathway elements to perturb endocrine response, notably to estrogen deprivation. These studies include overexpression of the growth factors heregulin- $\beta 2$ (Tang et al. 1996), fibroblast growth factor (FGF)-4 (McLeskey et al. 1993), insulin-like growth factor (IGF)-II (Daly et al. 1991, Abdul-Wahab et al. 1999) and transforming growth factor (TGF $\beta$ )-1 (Arteaga et al. 1993), and also growth factor receptors such as EGFR and IGF-1R (Van Agthoven et al. 1992, Miller et al. 1994, Guvakova \& Surmacz 1997, Abdul-Wahab et al. 1999). The receptor HER2 also appears to contribute to resistance either directly when over-expressed (Benz et al. 1993, Liu et al. 1995, Pietras et al. 1995) or indirectly as the preferred heterodimerization partner of liganded erbB receptor family members (Knowlden et al. 2003b). Furthermore, gene transfer of constitutively active growth factor signaling enzymes 
including Ras family members (Yu \& Feig 2002), Raf-1 (ElAshry et al. 1997), MAP kinase (Donovan et al. 2001, Oh et al. 2001), Akt (Campbell et al. 2001, Kurokawa \& Arteaga 2003), and protein kinase (PK) C (Tonetti et al. 2000) have all been associated with resistance, as has aberrant expression of nuclear transcription factors such as AP-1 (Smith et al. 1999).

Several mechanisms appear able to contribute to the increases in growth factor signaling in breast cancer cells that can promote endocrine resistance. These include genetic alterations in their key components (gene amplification, mutation etc.), best illustrated by HER2, where gene amplification is a feature of $30 \%$ breast cancers de novo (Tsuda 2001). However, adaptive events can also contribute, known to be instigated by diverse therapeutic strategies. Since growth factor pathways have been demonstrated to influence, and be influenced by, ER $\alpha$ signaling (Nicholson \& Gee 2000, Nicholson et al. 2001b, 2003, 2004, Hutcheson et al. 2003, Johnston et al. 2003), it is perhaps not surprising that adaptive events in growth factor pathways also occur when breast cancer cells are subjected to therapies that suppress ER $\alpha$ signaling. Thus, in vitro data have demonstrated that upregulation of EGFR (Chrysogelos et al. 1994, de Fazio et al. 1997, Yarden et al. 2001, Wilson \& Chrysogelos 2002, Gee et al. 2003) and HER2 (Russell \& Hung 1992, Bates \& Hurst 1997) occurs in several $E R \alpha+$ endocrine responsive breast cancer cells when they are subjected to estrogen deprivation, while in clinical disease increases in HER2 have been detected in serum during ovarian ablation (Luftner et al. 2003). A particularly common adaptive feature during response to long-term estrogen deprivation of in vitro and in vivo models appears to be increased MAP kinase activation (Coutts \& Murphy 1998, Jeng et al. 2000, Martin et al. 2003, Santen et al. 2004). Parallel adaptive data have been described for antiestrogens, again exemplified by our MCF-7 cell studies demonstrating that the initial response to tamoxifen (or fulvestrant) is associated with de-repression of the inhibitory effect of estrogen exposure on EGFR and HER2, with resultant increases in MAP kinase and also Akt signaling occurring during treatment (McClelland et al. 2001, Gee et al. 2003). Our extensive observations of these cells have clearly demonstrated that these adaptive events facilitate cell survival in the presence of anti-hormones (explaining incomplete initial anti-tumor activity) and ultimately promote proliferation and hence development of resistance (Gee et al. 2003, Nicholson et al. 2004). Similarly, emerging clinical studies are confirming up-regulation of various growth factor signaling elements, including HER2, that are apparent at the time of tamoxifen relapse (Gee et al. 1999, 2002, Johnston et al. 1999, Dowsett et al. 2003).
Growth factor signaling clearly has considerable potential to promote endocrine resistance. In the following sections, data will be presented demonstrating that altered growth factor signaling (either apparent de novo, or adapting during estrogen depletion) can contribute to development and growth of phenotypes resistant to estrogen deprivation. This appears to occur by a number of mechanisms that are also likely to be relevant when considering resistance to antiestrogens. The first of these resistance mechanisms is ER $\alpha$-dependent, where increased growth factor signaling elements act to hypersensitize breast cancer cells to residual estrogens (and in the case of challenge with the anti-estrogen tamoxifen, enhance its agonistic capability). The second mechanism, proposed by our own studies, indicates again that growth factor signaling elements can promote resistance to estrogen deprivation in an ER $\alpha$-dependent manner, but not by obviously increasing sensitivity to residual estrogens. Subsequent responses to anti-hormonal measures that further deplete $E R \alpha$ signaling (e.g. fulvestrant) are observed in both these forms of resistance, since interplay between $E R \alpha$ and growth factor signaling elements is a unifying feature. Thirdly, however, an ER $\alpha$-independent mechanism can be employed where growth factor signaling promotes proliferation in the presence of endocrine agents under conditions of markedly reduced ER $\alpha$ expression and/or signaling. Indeed, at its extremes, there is tantalizing evidence to suggest that growth factor signaling may even allow progression to an $\mathrm{ER} \alpha$ negative $(\mathrm{ER} \alpha-)$ phenotype.

\section{Increased growth factor signaling elements contribute to adaptive hypersensitivity in breast cancer cells by interplay with $\mathrm{ER} \alpha$}

\section{Adaptive estrogen hypersensitivity during estrogen deprivation}

Estrogen deprivation of various endocrine responsive breast cancer cell models (including MCF-7 and T47D) in vitro and in vivo is associated with an initial inhibitory response. However, studies from several laboratories have demonstrated that estrogen deprivation in the long-term is associated with development of an estrogen hypersensitive state, whereby the exquisitely low (non-physiological) amounts of estrogens remaining after estrogen deprivation appear sufficient to allow development and maintenance of tumor cell growth. Indeed, in one instance (Santen et al. 2004), dose-response data show that a 4-log lower concentration of estradiol $\left(10^{-14} \mathrm{M}\right)$ is able to stimulate the growth of the resistant cells in comparison with the parental MCF-7 cell line. Furthermore, since the estrogen hypersensitivity dose-response curve is bell-shaped, 
physiological levels of estradiol $\left(10^{-10} \mathrm{M}\right)$ are growth inhibitory (an event mediated through estradiol-induced Fas/FasL and hence apoptosis; Fernandez et al. 1998, Song et al. 2001, Martin et al. 2003, Song \& Santen 2003, Santen et al. 2004). Clinical observations imply that an adaptive shift in estrogen sensitivity also occurs in breast cancer patients when estrogen/ER $\alpha$ signaling is compromised and that this is important in the emergence of resistance. Thus, endocrine therapies that systematically reduce estrogen signaling can be sequentially effective in breast cancer patients after resistance to initial antihormonal challenge develops (i.e. 'manipulating the estrostat'; Lonning 2001).

Based on various model system data, overlapping explanations involving the predominant interplay between growth factor elements and non-genomic or genomic ER $\alpha$ signaling pathways have been proposed for the phenomenon of adaptive estrogen hypersensitivity that is associated with acquisition of resistance to estrogen deprivation. Unifying features of these hypersensitivity mechanisms are increased ER $\alpha$ and enhanced activation of MAP kinase and phosphatidylinositol-3-OH kinase (PI3K) signaling, phenotypic changes that appear to very commonly arise during prolonged estrogen deprivation. Indeed, such elements appear critical since, as will be described below, all these models show second-line responses to agents depleting such signaling (i.e. the selective $E R \alpha$ down-regulator, fulvestrant, and signal transduction inhibitors respectively).

\section{Dominant 'non-genomic' ER $\alpha /$ growth factor signaling mechanism}

An MCF-7 model of long-term estrogen deprivation (LTED) has been derived by Richard Santen's group by use of phenol red-free medium containing charcoalstripped serum, where the estradiol concentration is reduced to $10^{-13} \mathrm{M}$. Following a growth inhibitory phase of 3-6 months, LTED cells acquired resistance and resumed substantial proliferation (Santen et al. 2004). Such cells are markedly hypersensitive when challenged with estradiol, as described above, and in vivo xenograft model system data from the group parallel these in vitro findings (Masamura et al. 1995). In these cells that have adapted to grow in the presence of residual estrogens, Santen has placed emphasis on increased utilization of 'nongenomic' cell membrane ER $\alpha$. His group has shown that $\mathrm{ER} \alpha$ translocated to the plasma membrane is markedly elevated in LTED cells in comparison with parental MCF-7 cells. On binding of estrogen, this membrane $\mathrm{ER} \alpha$ is able rapidly to recruit classical growth factor signal transduction (Santen et al. 2004). The estrogen-primed membrane $\mathrm{ER} \alpha$ is thus able efficiently to associate with, and phosphorylate, the adaptor protein
Shc in LTED (Santen et al. 2004). It is notable that Shc is a key modulator of several tyrosine kinase receptors including EGFR and IGF-1R (Pelicci et al. 1995), and such growth factor receptors may contribute to the increased translocation of $\mathrm{ER} \alpha$ to the membrane and participate in its coupling to Shc on estrogen binding. Of note in the LTED cells is IGF-1R, where Santen and colleagues have shown that both Shc and ER $\alpha$ coimmunoprecipitate using an anti-IGF-1R antibody, and that binding of ER $\alpha$ to the IGF-1R occurs within minutes of the addition of estradiol (Santen et al. 2004, Song et al. 2004). Shc subsequently binds to the adaptor proteins Grb2 and Sos and rapidly activates the Ras/Raf/Mek/ MAP kinase signaling cascade (Santen et al. 2001, 2003 2004, Song et al. 2002a,b). Estradiol was thus shown to stimulate Shc and marked increase MAP kinase phosphorylation in a time- and dose-dependent fashion in LTED. These events were blocked by the ER $\alpha$ downregulator, fulvestrant, indicating that $E R \alpha$ is a key upstream component of such signaling rather than MAP kinase activation being derived from constitutive, ER $\alpha$ independent growth factor receptor activity/growth factor secretion in LTED cells (Santen et al. 2001, 2003, 2004, Song et al. 2002a). Certainly there is no evidence of constitutive TGF $\alpha$ over-expression in LTED cells from several studies (Herman \& Katzenellenbogen 1994, Jeng et al. 1998, 2000, Santen et al. 2001, 2004).

Similarly, the blockade of MAP kinase activation in LTED by PP-2, a specific c-Src kinase inhibitor, indicates that c-Src kinase is also an important regulator of such signaling (Song et al. 2002b, Santen et al. 2004). The pivotal role for increased activation of MAP kinase in determining the estrogen hypersensitive growth adopted by LTED has been confirmed by abrogation of their basal proliferation and hypersensitive responses to estrogen in vivo using the MAP kinase inhibitors, PD98059 or U0126 (Shim et al. 2000, Yue et al. 2002, Santen et al. 2004). As further proof, the addition of TGF $\alpha$ to parental MCF-7 cells in vitro in order to augment their MAP kinase activity promoted a 2-log increase in sensitivity to growth stimulation by estradiol (Yue et al. 2002, Santen et al. 2004). Associated growth end-points of the elevated nongenomic ER $\alpha /$ MAP kinase signaling pathway identified to date in LTED include phosphorylation of ELK-1, a regulator of proliferative activity, and cell membrane changes (Song et al. 2002a,b, Santen et al. 2003, 2004).

Interestingly, however, MAP kinase does not appear to be the only intracellular signaling pathway central to estrogen hypersensitive growth of LTED, since it was observed that MAP kinase inhibitors were unable fully to block this event. Hypersensitive cells in vitro also exhibited enhanced activation of Akt, p70 S6 kinase and eukaryotic initiation factor-4E binding protein (4E-BP1), 
key effectors of the PI3K pathway (Yue et al. 2003, Santen et al. 2004). In other cell systems, estrogen has been shown to be capable of activating PI3K in a nongenomic manner, triggering association between $\mathrm{ER} \alpha$, cSrc and the p85 PI3K subunit, with this event converging on cell cycle progression (Castoria et al. 2001). In LTED, dual-inhibition of PI3K with LY294002 and MAP kinase with U0126 was able completely to reverse estrogen hypersensitivity (Yue et al. 2003, Santen et al. 2004). Thus, it appears that co-ordinated activity of PI3K and MAP kinase promotes adaptive hypersensitivity to estrogen deprivation and hence allows LTED growth. Interestingly, changes in MAP kinase and Akt have been associated with endocrine resistance and poorer prognosis in breast cancer samples from patients, suggesting clinical relevance of these signaling elements (Gee et al. 2001, Perez-Tenorio et al. 2002) .

While rates of $E R \alpha$-mediated gene transcription are certainly enhanced basally in LTED, global hypersensitivity to estradiol at the level of classically estrogenregulated genes is not apparent (Jeng et al. 1998). Furthermore, MAP kinase inhibition is ineffective on such genes in LTED, an observation discordant with the growth inhibitory effects of this agent (Jeng et al. 2000). Thus, Santen's data suggest that it is an enhanced nongenomic estrogen $/ \mathrm{ER} \alpha$ mechanism that drives elevated MAP kinase/Akt signaling and thereby promotes growth in the presence of very low estrogen levels (Santen et al. 2004), rather than a predominant genomic pathway, where estrogens would classically interact with nuclear $\mathrm{ER} \alpha$ to elevate gene transcription (for example, expression of growth factor ligands such as TGF $\alpha$ that could subsequently prime MAP kinase/Akt (Hutcheson et al. 2003)). However, additional studies from Santen's group suggest that some degree of undefined, synergistic interaction between non-genomic and genomic pathways does occur at the level of cell cycle regulators, such as E2F1, in the promotion of LTED growth (Yue et al. 2002, Santen et al. 2003, 2004).

\section{Dominant 'genomic' $E R \alpha / g r o w t h$ factor signaling mechanism}

By way of contrast, Johnston and Dowsett (2003) have suggested that enhanced ER $\alpha$ function and the estrogen hypersensitive state arises primarily as a result of increased cross-talk between various growth factor pathways at the level of nuclear ER $\alpha$ in long-term estrogendeprived breast cancer cells. In their model, estrogendeprived breast cancer cells initially pass through a stage of estrogen hypersensitivity (LTED-H; hypersensitivity profile similar to that described by Santen and colleagues). In accordance with many models (Katzenellenbogen et al. 1987, Welshons \& Jordan 1987, Fernandez et al. 1998,
Santen et al. 2004), these cells again have elevated nuclear $\mathrm{ER} \alpha$. Interestingly, the $\mathrm{ER} \alpha$ in LTED-H is highly phosphorylated on Ser118 residue in its AF-1 domain in the absence of estrogen, suggesting a key contribution to hypersensitive growth (Chan et al. 2002).

Surprisingly, however, after 80 weeks of culture under estrogen-deprived conditions, ER $\alpha$ appears to function independently of exogenous estradiol (LTED-I). This 'independent' state has similarly been reported in other prolonged estrogen deprivation studies (Darbre \& Daly 1990, Daly et al. 1990). Dowsett's group have hypothesized that this phase of growth on long-term withdrawal has actually become 'super-sensitive' to residual estrogens (Chan et al. 2002, Martin et al. 2003). Critically, the steroid hormone-depleted culture conditions incorporated insulin into the growth medium for the development and maintenance of LTED-I. The group reported that exclusion of insulin resulted in an approximately 50\% drop in basal growth rate of LTED-I cells and restoration of estrogen hypersensitivity (Martin et al. 2003). These data led the group to suggest that the supersensitive LTED-I cells are growing maximally in the insulinsupported media and therefore that exogenous estrogens can have no further growth-promoting action, explaining the apparent LTED-I state. Characterization of the LTED-I cells has revealed that they express elevated ER $\alpha$ with increased phosphorylation on Ser118. They also exhibit increased transcriptional activity at estrogen response elements (EREs) that are hypersensitive to estrogen stimulation, and their growth is inhibited by fulvestrant. Clearly in this model, therefore, cross-talk between ER $\alpha$ signaling pathways and insulin at the level

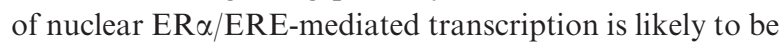
pivotal to the adaptation of the cells to estrogen deprivation. Although the mechanics of the cross-talk leading to estrogen hypersensitivity and super-sensitivity are undoubtedly complex, comprehensive studies from the group have demonstrated, in addition to elevated ER $\alpha$, a key involvement for increased IGF-1R and HER2 signaling in LTED-I. These promote activation of MAP kinase, $\mathrm{ER} \alpha$ (and ER $\alpha$ co-activator) phosphorylation, ERE transcriptional regulation, LTED-I cell growth and supersensitivity to residual estrogens. Increases in IGF-1R have also been implicated in adaptation to long-term estrogen deprivation by Stephen et al. (2001), with some growth inhibitory effect of IGF-1R blockade using the IGF-1R specific antibody $\alpha$ IR3 noted in their model. Increases in HER2 signaling have also been noted on development of acquired resistance to estrogen deprivation in HER-2-transfected MCF-7 cells (Massarweh et al. 2003). Of note, the increased activation of MAP kinase in LTED-I cells was not triggered in a rapid manner by 
estrogen, indicating that non-genomic $\mathrm{ER} \alpha$ signaling is not a dominant contributor (Martin et al. 2003).

Interestingly, Dowsett's group showed that inhibition of MAP kinase activation only partially reduced basal ERE transcriptional activity and was ineffective in blocking Ser118 ER $\alpha$ phosphorylation. These data imply not only an involvement for additional interactive signaling elements in LTED-I, but also that enhancement of ER $\alpha$ transcriptional activity occurs via additional ER $\alpha$ phosphorylation sites (e.g. Ser167; Campbell et al. 2001) or perhaps via augmented co-activator activity (e.g. AIB1; Font de Mora \& Brown 2000). In this regard, p $90^{\text {RSK }}$ and PI3K signaling were shown to be additional contributory elements, data in total suggesting that a network of kinases is recruited on estrogen withdrawal to enhance growth sensitivity to residual estrogens via improvement of $\mathrm{ER} \alpha$ transcriptional activation.

\section{Adaptive hypersensitivity to the agonistic effects of tamoxifen and estrogen during antiestrogen treatment}

The process of adaptive hypersensitivity, involving increases in growth factor signaling and its cross-talk with $\mathrm{ER} \alpha$, could feasibly be initiated not only by estrogen deprivation strategies, but also by interference with the estrogen/ER $\alpha$ response pathway using antiestrogens. This would be manifested by enhanced growth sensitivity not only to estrogens, but also to the agonistic effects of selective ER modulators (SERMs) such as tamoxifen, thereby allowing the emergence of tamoxifen-resistant growth. In agreement with this concept, MCF-7 breast cancer xenografts, while initially inhibited by tamoxifen, are growth-stimulated by this antiestrogen in the longterm and are also estrogen hypersensitive (Gottardis \& Jordan et al. 1988, Osborne et al. 1991). Furthermore, in several acquired tamoxifen-stimulated xenograft MCF-7 and T47D models, very prolonged tamoxifen exposure is associated not only with tamoxifen stimulation but also tumoricidal effects of estrogen, a feature described above with excessive estradiol exposure of long-term estrogendeprived cells (Jordan et al. 2003). Growth-enhancing effects of tamoxifen appear also to be a feature of some breast cancers clinically, as evidenced by antiestrogen withdrawal responses reported in $\sim 20 \%$ of patients (Clarke et al. 2003). Moreover, enhanced tumor sensitivity to tamoxifen agonism may explain the initial superiority of AIs in the clinic, since these agents more effectively eliminate estrogens while exerting no agonistic effects (Mouridsen et al. 2001). A growth contribution for tamoxifen-bound $\mathrm{ER} \alpha$ is similarly inferred by the frequency of second-line responses to either fulvestrant or AIs in the clinic (Howell et al. 1996, Buzdar et al. 1997).
Interestingly, the above described models for the development of adaptive estrogen hypersensitivity/supersensitivity do show many phenotypic similarities with those generated for the study of ER $\alpha+$ SERM resistance. Supportive data have been derived both from in vitro and in vivo models of acquired resistance (reviewed in Nicholson et al. 2004), and are now beginning to emerge from clinical sample profiling at relapse (Gee et al. 2002, Dowsett et al. 2003). Schiff et al. (2003, 2004) provide an overview of experimental tamoxifen resistant data that are particularly complementary to the above-described mechanisms for adaptive hypersensitivity during estrogen deprivation. The group describe that both non-genomic (membrane, predominantly at the caveolar domains) and genomic (nuclear) $\mathrm{ER} \alpha$ signaling influence, and are influenced by, growth factor signaling pathways resulting in enhanced agonistic activity of the tamoxifen-ER $\alpha$ complex in tamoxifen-resistant cells. In such cells, membrane $\mathrm{ER} \alpha$ (perhaps even activated by tamoxifen; Figtree et al. 2000) rapidly activates cell surface tyrosine kinase receptors (such as EGFR (Razandi et al. 2003), HER2 (Chung et al. 2002) or IGF-1R (Kahlert et al. 2000)), leading to signaling through p21Ras/MAP kinase and PI3K/Akt. These protein kinases are able to phosphorylate nuclear ER $\alpha$ in its AF-1 domain, as well as phosphorylate other key components of the transcriptional machinery, notably co-activators (Bunone et al. 1996, Font de Mora \& Brown 2000, Campbell et al. 2001). This results in re-activation of transcription by the tamoxifen-occupied ER $\alpha$ complex, increases in growth factor expression to re-enforce the signaling loop, and cell growth in the presence of antiestrogen (Schiff et al. 2003, 2004).

Clearly, this ER $\alpha$-growth factor signaling loop could be dominant under conditions where growth factor receptors were either elevated de novo or were promoted during antiestrogen challenge. HER2 overexpression could thus serve to augment this signaling loop de novo, markedly increasing MAP kinase activation and its target coactivator AIB1 to subsequently enhance nuclear ER $\alpha$ signaling and exaggerate the agonistic activity of the tamoxifen-ER $\alpha$ complex (Font de Mora \& Brown 2000, Schiff et al. 2003, 2004). Certainly, in de novo tamoxifenresistant MCF-7/HER2 cells, tamoxifen is agonistic yet these cells remain sensitive to estrogen deprivation (Massarweh et al. 2003). The concept is particularly exciting since clinical observations are indicating that HER2/AIB1-co-expressing tumors do fare poorly when treated with adjuvant tamoxifen (Osborne et al. 2003), while preliminary adjuvant and neoadjuvant studies have revealed that HER2+ or EGFR+ patients are relatively resistant to this antiestrogen de novo, yet retain sensitivity to the AIs, anastrozole or letrozole (Dowsett et al. 2001, 
$A$

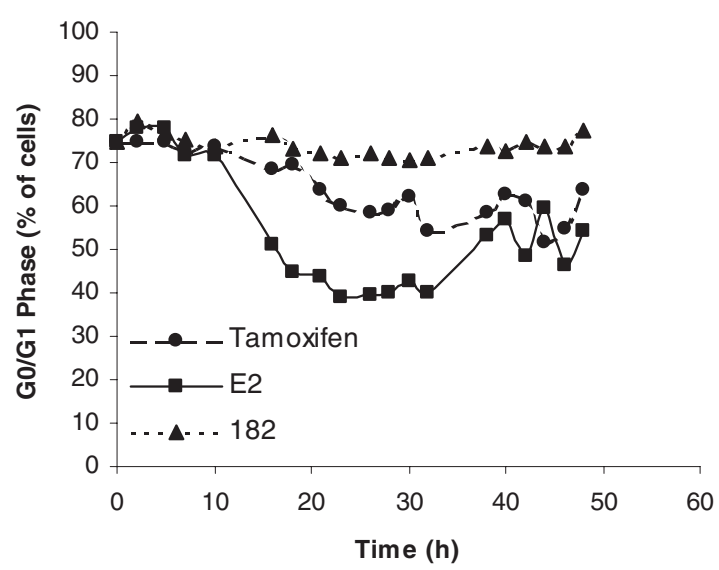

B

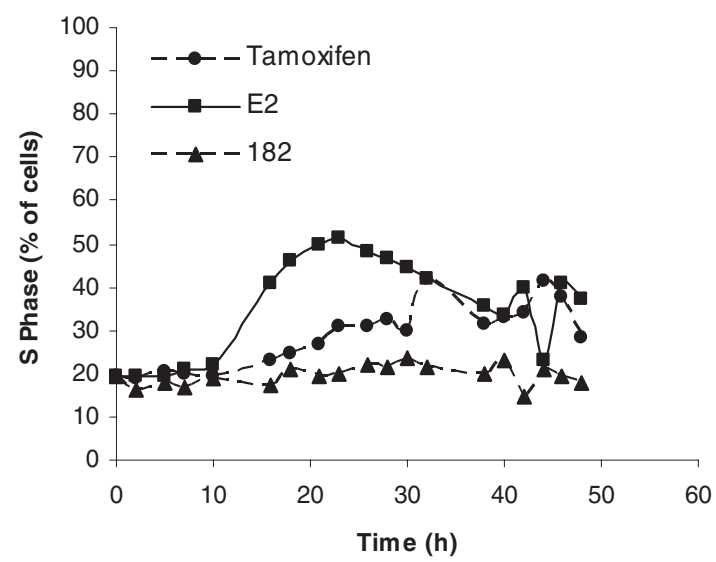

Figure 1 Regrowth of fulvestrant-treated tamoxifen-resistant cells in the presence of estradiol and tamoxifen. Tamoxifen-resistant MCF-7 cells were grown for 2 days in charcoal-stripped $5 \%$ FCS containing fulvestrant $\left(10^{-7} \mathrm{M}\right)$. The cells were then exposed to continuing fulvestrant (182), estradiol $\left(E 2 ; 10^{-7} \mathrm{M}\right)$ or tamoxifen $\left(10^{-7} \mathrm{M}\right)$. At the time points indicated cells were subjected to FACS analysis and the proportion of cells in Go/G1 (A) and S-phase (B) of the cell cycle was recorded.

Ellis et al. 2001). Adaptive changes in growth factor signaling elements acquired during therapy may also promote tamoxifen agonistic activity. Adaptive increases in EGFR/HER2 signaling are certainly promoted in endocrine responsive cells during long-term tamoxifen challenge (Gee et al. 2003). Moreover, study of several in vivo and in vitro models has revealed that elevated growth factor signaling is subsequently maintained in the acquired resistant phenotype, is recruited to growth and, importantly, is highly interactive with $\mathrm{ER} \alpha$ (reviewed in Nicholson et al. 2004). HER2 overexpression and its cross-talk with $\mathrm{ER} \alpha$ appears to be a common feature of acquired tamoxifen-stimulated MCF-7 and T47D xenograft models (Schafer et al. 2003). In parallel, Berstein et al. (2003, 2004) have demonstrated that long-term tamoxifen treatment of MCF-7 breast cancer cells (LTTT) in a castrated in vivo xenograft model is associated with early adaptive increases in MAP kinase signaling. This event promotes hypersensitivity to the agonistic effects of this anti-hormone and subsequently to estradiol, where the critical role of such signaling is evidenced by marked growth inhibitory effects of a Ras antagonist.

In our own acquired tamoxifen-resistant in vitro model that emerged following prolonged exposure of MCF-7 to this antiestrogen, we have observed upwards of 20-fold increases in total and activated EGFR/HER2, with a corresponding increase in phosphorylation of MAP kinase, Akt and nuclear ER $\alpha$ on the AF-1 residues Ser118 and Ser167 (Nicholson et al. 2001b, 2003, 2004, Britton et al. 2002, 2003, Hutcheson et al. 2003, Knowlden et al. 2003b, Jordan et al. 2004). Importantly, we have established that phosphorylation of nuclear ER $\alpha$ and
$\mathrm{ER} \alpha$ transcription in these cells is under the control of EGFR, where EGF-like ligands further enhance these $\mathrm{ER} \alpha$ events and exposure to the EGFR-selective tyrosine kinase inhibitor, gefitinib, antagonises basal and EGFprimed $\mathrm{ER} \alpha$ phosphorylation and transcription (Britton et al. 2002, Hutcheson et al. 2003, Nicholson et al. 2003, 2004). This enhanced ER $\alpha$ activity appears to result in increased expression of the EGFR ligands TGF $\alpha$ and amphiregulin to generate a self-propagating autocrine growth regulatory loop in the tamoxifen-resistant cells, essentially converting a growth inhibitory drug into one that readily facilitates tumor cell growth (Hutcheson et al. 2003). Additionally, IGF-1R appears to contribute by activating the EGFR and thus enhancing its impact on ER $\alpha$ signaling. An IGF-II challenge not only leads to the expected increase in the phosphorylation of IGF-1R, but also to a reproducible secondary increase in EGFR activation (Knowlden et al. 2003a, Hutcheson et al. 2004, Nicholson et al. 2004). These events, together with the phosphorylation of the ER $\alpha$, can be blocked by inhibitors of IGF-1R signaling. The contribution of membrane-localized ER $\alpha$ to such signaling (if any) is currently being assessed by our group. Importantly, however, in this acquired tamoxifen-resistant model we have again noted that adaptive changes in growth factor pathways are associated both with tamoxifen agonism and enhanced sensitivity to estradiol. As may be seen from Fig. 1, following treatment of tamoxifen-resistant cells with fulvestrant to efficiently eliminate $\mathrm{ER} \alpha$, break the autocrine growth factor/ER $\alpha$ signaling loop and promote arrest of cells in Go/G1 (Fig. 1A), both estradiol and tamoxifen are able to induce substantial entry into the S-phase of the cell cycle (Fig. 1B) that translates out into 
growth promotion of these cells. Our preliminary data indicate that activation of Akt and increases in cyclin $\mathrm{E}$ are components of this escape mechanism.

In total, the above data indicate that adaptive tamoxifen hypersensitivity, in common with adaptive estrogen hypersensitivity during estrogen deprivation, can result from multiple levels of interplay between growth factor signaling cascades and membrane and/or nuclear $\mathrm{ER} \alpha$. These interactions are likely to play a key synergistic role in the resultant acquired resistant growth. Frequent second-line responses to fulvestrant in these models, as well as to appropriate anti-growth-factor strategies, confirm the pivotal role played by ER $\alpha$ and growth factor signaling.

\section{Increased growth factor signaling elements can interplay with ER $\alpha$ on estrogen deprivation of breast cancer cells in a manner not associated with adaptive hypersensitivity}

It is clear from the above studies of Santen and Dowsett that their experimental conditions of estrogen deprivation are associated with substantial changes in sensitivity of the resultant resistant cells to estrogen, where the availability of exogenous growth factors appears to impact on the underlying molecular mechanism. In order to examine this further, our group has recently developed and characterized a further in vitro model of resistance to estrogen withdrawal (MCF-7X) where cells are routinely grown in charcoal-stripped, heat-inactivated serum and therefore subject to growth regulation primarily by autocrine growth factor pathways and residual steroid hormone. In our new model, although rapid tumor cell growth was established after a marked inhibitory phase in MCF-7 cells of approximately 6 months and the cells could be further stimulated by estrogens, we have failed to reveal any evidence of estrogen hypersensitivity. This is despite functional, phosphorylated ER $\alpha$ in MCF7X cells and obvious growth inhibition by fulvestrant. Functional ER $\alpha$ and fulvestrant responses have similarly been reported in the $\mathrm{MCF}-7 / \mathrm{S} 9$ cell line that acquired resistance to serum-free culture conditions (Jensen et al. 2003). In addition, MCF-7X cells have readily detectable levels of activated MAP kinase and Akt. While we have failed, to date, to demonstrate a dominant role for MAP kinase signaling in these cells, we have observed that the PI3K inhibitor, LY294002, is effective, again suggesting an importance for the latter growth factor signaling element in promotion of estrogen deprivation.

Interestingly, in MCF-7X cells we have been unable to demonstrate a dominant growth factor-driven autocrine growth regulatory pathway, with for example, the cells being only weakly EGFR/HER2 positive and showing only extremely modest growth inhibition $(\sim 10 \%)$ with gefitinib or the humanized HER2-directed antibody, herceptin. The resistant cells are similarly only very weakly positive for IGF-1R and virtually unresponsive to IGF-1R ligands or inhibitors. We have now profiled the effects of multiple growth factors and medium growth supplements in our quest to reveal pathways that may be contributing to growth of MCF-7X cells. In this respect, the most obvious mitogenic factor that we have discovered for MCF-7X to date, other than estrogen, is the iron transporter transferrin (Li \& Qian 2002). Of note, MCF-7X cells express transferrin and show markedly increased levels of its receptor. Provocatively, PI3K signaling has been shown to interact with transferrin/ transferrin receptor by regulating its trafficking (Jess et al. 1996). Hence our studies in MCF-7X may have revealed a previously unknown role for the PI3K enzyme in its promotion of estrogen-deprived states. Excitingly, both PI3K signaling and transferrin receptor have been linked with proliferative activity and disease progression in breast cancer samples, suggesting clinical relevance (Elliott et al. 1993, Perez-Tenorio et al. 2002). Detailed study of the networking between PI3K, transferrin and $\mathrm{ER} \alpha$ in MCF-7X cells and its evolution during estrogen deprivation is obviously still required from our group. However, our data clearly demonstrate that ER $\alpha$-dependent adaptive resistance to estrogen withdrawal can occur by mechanisms that do not always enhance sensitivity to residual estrogens or recruit classical growth factor receptors (notably EGFR/HER2/IGF-1R), but again involves PI3K as an essential signaling element.

\section{Increased growth factor signaling elements can contribute to resistance to estrogen deprivation and antiestrogens in the presence of reduced or absent ER $\alpha$ expression/signaling in breast cancer cells}

Several studies have shown that increased growth factor signaling is capable of promoting proliferation of breast cancer cells under conditions of markedly reduced ER $\alpha$ expression and/or signaling. Thus, we have demonstrated that endocrine responsive MCF-7 cells that are significantly growth inhibited by the $\mathrm{ER} \alpha$ down-regulator, fulvestrant, may be stimulated to proliferate in the presence of this agent by exogenous heregulin $\beta 1$ or IGF-I (Fig. 2A) despite their ER $\alpha$ being barely detectable. Under such conditions, such growth factors appear able considerably to up-regulate MAP kinase and Akt phosphorylation in a manner that is proportional to their ability to induce cell proliferation, and the cells are refractory to any endocrine manipulation (Tang et al. 1996, Atlas et al. 2003) (Fig. 2C). 

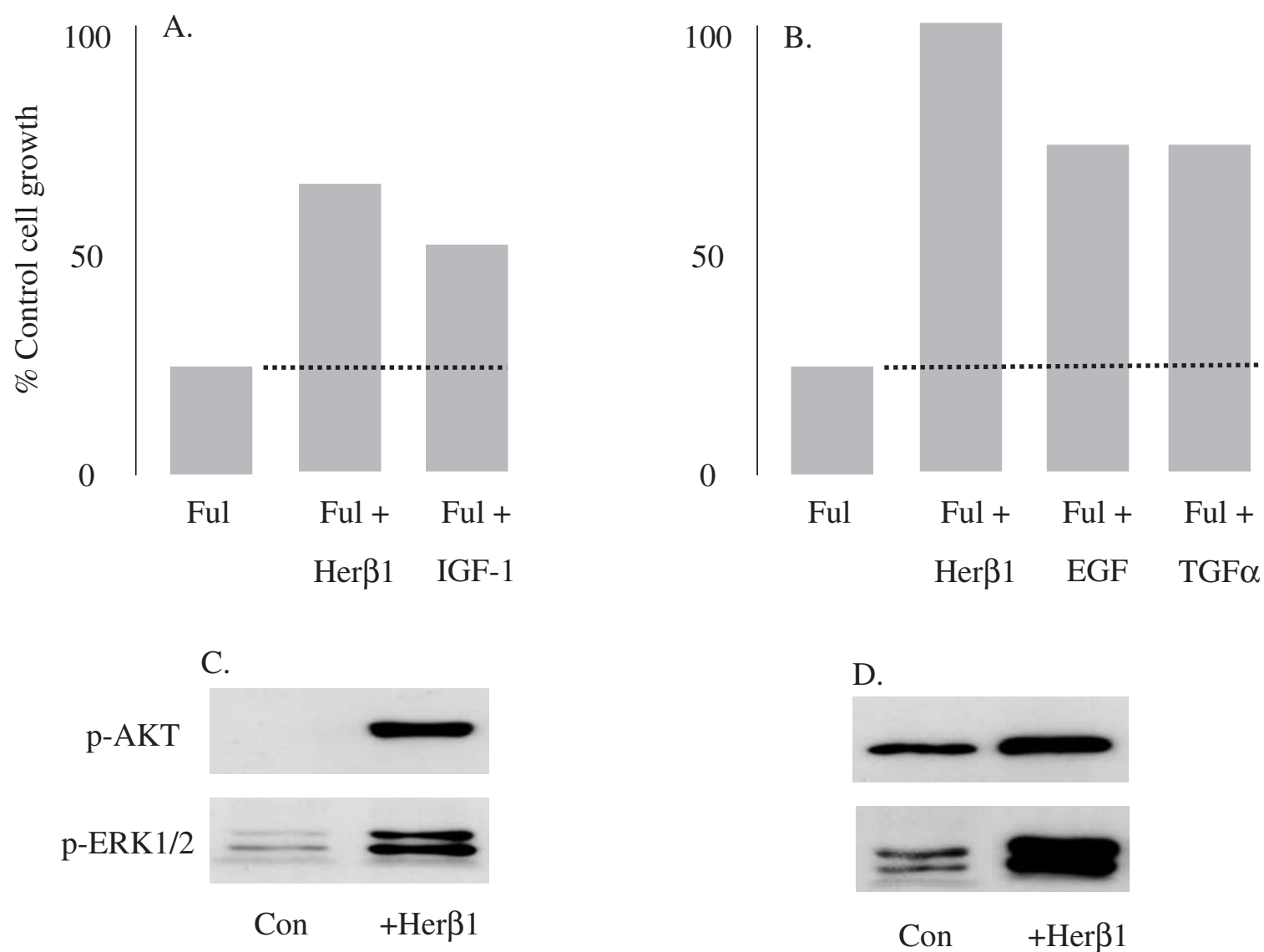

Figure 2 Effect of growth factors on fulvestrant-treated breast cancer cells. Wild-type (A and C) and tamoxifen-resistant (B and D) cells were grown for $24 \mathrm{~h}$ in charcoal-stripped $5 \%$ FCS containing fulvestrant (Ful; $10^{-7} \mathrm{M}$ ). The cells were then maintained in fulvestrant in the presence or absence of the growth factors $(100 \mathrm{ng} / \mathrm{ml})$ heregulin $\beta 1$ (Her $\beta 1)$, insulin-like growth factor-I (IGF-1), epidermal growth factor (EGF) or transforming growth factor- $\alpha$ (TGF $\alpha$ ). Cells were harvested for Western analysis of phosphorylation of AKT (p-AKT) and erk1/2 MAP kinase (p-ERK1/2) after $10 \mathrm{~min}$ or for cell counting after 7 days. Con, control - no growth factors.

Similarly, following inhibition of the EGFR/ER $\alpha$ autocrine growth signaling loop in our acquired tamoxifen resistant sub-line using fulvestrant, re-activation of MAP kinase and Akt by exogenous heregulin $\beta 1$ (Fig. 2D) appears sufficient to maintain high levels of cell growth in the presence of fulvestrant (Fig. 2B) where again the ER $\alpha$ protein is virtually absent and $\mathrm{ER} \alpha / \mathrm{ERE}$ activity is abrogated (Hutcheson et al. 2003, Nicholson et al. 2003, 2004). Since similar actions are produced by EGF and TGF $\alpha$ (Fig. 2B), extreme levels of growth factor signaling appear able to promote a 'complete endocrine insensitive' state.

Moreover, there is evidence that increased growth factor signaling can also act to reduce $\mathrm{ER} \alpha$ expression and/or function. Growth factor dose-response and timecourse studies suggest that while $\mathrm{ER} \alpha$ activity and transcription can be activated as described in the section 'Increased growth factor signaling elements contribute to adaptive hypersensitivity in breast cancer cells by interplay with ER $\alpha$ ' above, under certain extreme (as yet poorly defined) conditions blockade of these events is also a possible outcome. Since chronic ER $\alpha$ activation by estrogen can be associated with $\mathrm{ER} \alpha$ downregulation (Pink \& Jordan 1996), it is certainly feasible that constitutive/chronic activation of $\mathrm{ER} \alpha$ by growth factor signaling could similarly result in a decline in ER $\alpha$. Stoica and colleagues (Martin et al. 1995, Stoica et al. 1997, $2000 a, b)$ systematically describe the capability of exogenous EGF, IGF-I, TGF $\beta$ and 12-o-tetradecanoyl pherbol13-acetate (TPA) to down-regulate $\mathrm{ER} \alpha \mathrm{mRNA}$ and protein in MCF-7 cells via mechanisms involving increased growth factor signaling through EGFR, PI3K/ Akt, phosphorylated (p) PKA and PKCs. In the case of prolonged treatment with the PKC activator TPA, ER $\alpha$ protein levels were reduced by $80 \%$ and there was a parallel decrease in ER $\alpha \mathrm{mRNA}, \mathrm{ER} \alpha$ ligand binding, 
A

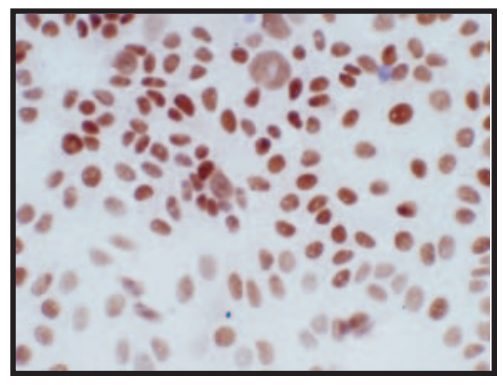

B

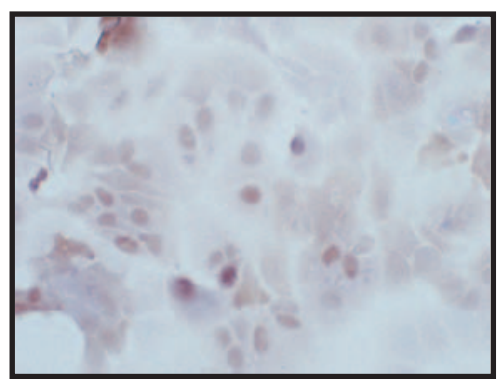

C

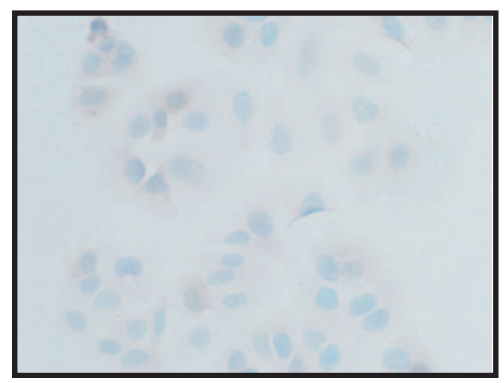

Figure 3 ER expression in breast cancer cells. Wild-type MCF-7 cells (A) and short- (B) and long (C)-term fulvestrant (faslodex)resistant cells were cultured for 7 days on coverslips. The cells were then fixed and processed for ER immunostaining.

$\mathrm{ER} \alpha$ binding to DNA and $\mathrm{ER} \alpha / \mathrm{ERE}$ activity (Martin $e t$ al. 1995). TPA depletion of ER $\alpha$ appeared to be blocked by a PKC inhibitor (Saceda et al. 1991) and involved downstream activation of the AP-1 nuclear transcription factor complex (Doucas \& Yaniv 1991). Further agents shown to depress $\mathrm{ER} \alpha$ or its transcriptional activity include heregulin $\beta 1$ (Mueller et al. 1995, Tang et al. 1996) and retinoids (Demirpence et al. 1992).

At its extremes, sustained growth factor suppression of $E R \alpha$ expression/function may even promote $E R \alpha$ negativity. This condition appears achievable in vitro during extended challenge with endocrine strategies. Such cells are subject to the influences of prolonged, elevated growth factor signaling that evolves during treatment. For example, we have recently noted that our fulvestrantresistant cells, whose growth is promoted primarily via increased EGFR/MAP kinase signaling in the presence of minimal ER $\alpha$ levels (McClelland et al. 2001), have now developed a fully ER $\alpha$-phenotype following extended culture in this pure antiestrogen (Fig. 3). Interestingly, while early passages of the fulvestrant-resistant sub-line were able to regain full $\mathrm{ER} \alpha$ signaling on removal of fulvestrant (McClelland et al. 2001), our recent studies have revealed that the long-term resistant cells are unresponsive to estrogens on antiestrogen removal and significant levels of $E R \alpha$ are not recovered even after several months withdrawal. Prolonged estrogen deprivation has similarly been associated with evolution of an ER $\alpha$ - phenotype in T47D cells (Murphy et al. 1989, 1990, Pink et al. 1996), as exemplified by the T47D:C4 sub-line that expresses TGF $\alpha$ and EGFR, as well as markedly elevated PKC $\alpha$ and AP-1 activity (Murphy et al. 1990, Tonetti et al. 2000, Chisamore et al. 2001).

Further supportive evidence for this transition can be drawn from several transfection studies where growth factor signaling elements introduced into $\mathrm{ER} \alpha+$ breast cancer cells can act to deplete $\mathrm{ER} \alpha$ and impair $\mathrm{ER} \alpha$ function. In our own study, we have shown that constitutive up-regulation of MEK1 in MCF-7 cells leads to a substantial increase in MAP kinase activation, decreased $E R \alpha$ levels and marked loss of progesterone receptor (PR) expression (R A McClelland, J M W Gee \& R I Nicholson, unpublished observations). Similarly, ElAshry and colleagues have noted precipitous falls in ER $\alpha$ mRNA and protein following transfection of constitutively active HER2, MEK ( $\Delta$ mek), Raf1 ( $\Delta$ raf) or ligandstimulated EGFR into MCF-7 cells (Liu et al. 1995, Pietras et al. 1995, El-Ashry et al. 1997, Oh et al. 2001), with a parallel loss of estrogen-mediated induction of $\mathrm{pS} 2$ and PR and a marked suppression of activity of EREreporter gene constructs in transient transfection experiments that could not be overcome by estradiol treatment. Not surprisingly, the severe impact of elevated growth factor signaling on ER $\alpha$ expression and function also resulted in estrogen independence and antiestrogen resistance. Overexpression of Akt, PKC $\alpha$ and AP-1 components has similarly been linked with decreased $\mathrm{ER} \alpha$ function, loss of $\mathrm{ER} \alpha$ and endocrine-resistant states (Doucas \& Yaniv 1991, Tzukerman et al. 1991, Smith et al. 1999).

In total, these data provide substantial evidence that while increased growth factor signaling can act to facilitate $E R \alpha$ function, at its extremes it may promote tumor cell growth in an apparently $E R \alpha$-independent manner and may even encourage dislocation from ER $\alpha$ signaling and promote evolution of an ER $\alpha$ - phenotype. Interestingly, tumors with exaggerated EGFR signaling, whether $\mathrm{ER} \alpha+$ or $\mathrm{ER} \alpha-$, can be endocrine insensitive on presentation (Nicholson et al. 1994, 2004, Gee et al. 2001, 2002), and while not examined in any depth, such a phenotype may also contribute to the significant cohort of patients who fail to respond to second-line endocrine challenge (Gee et al. 2002). The conditions under which this transition to $\mathrm{ER} \alpha+$ complete endocrine insensitivity or $\operatorname{ER} \alpha$ negativity occurs remains poorly defined; however, it is perhaps significant that our fulvestrant-resistant sub-line that shows markedly reduced $\mathrm{ER} \alpha \mathrm{mRNA}$ and $\mathrm{ER} \alpha$ protein appears more susceptible to the generation 


\section{Increased growth factor signalling}

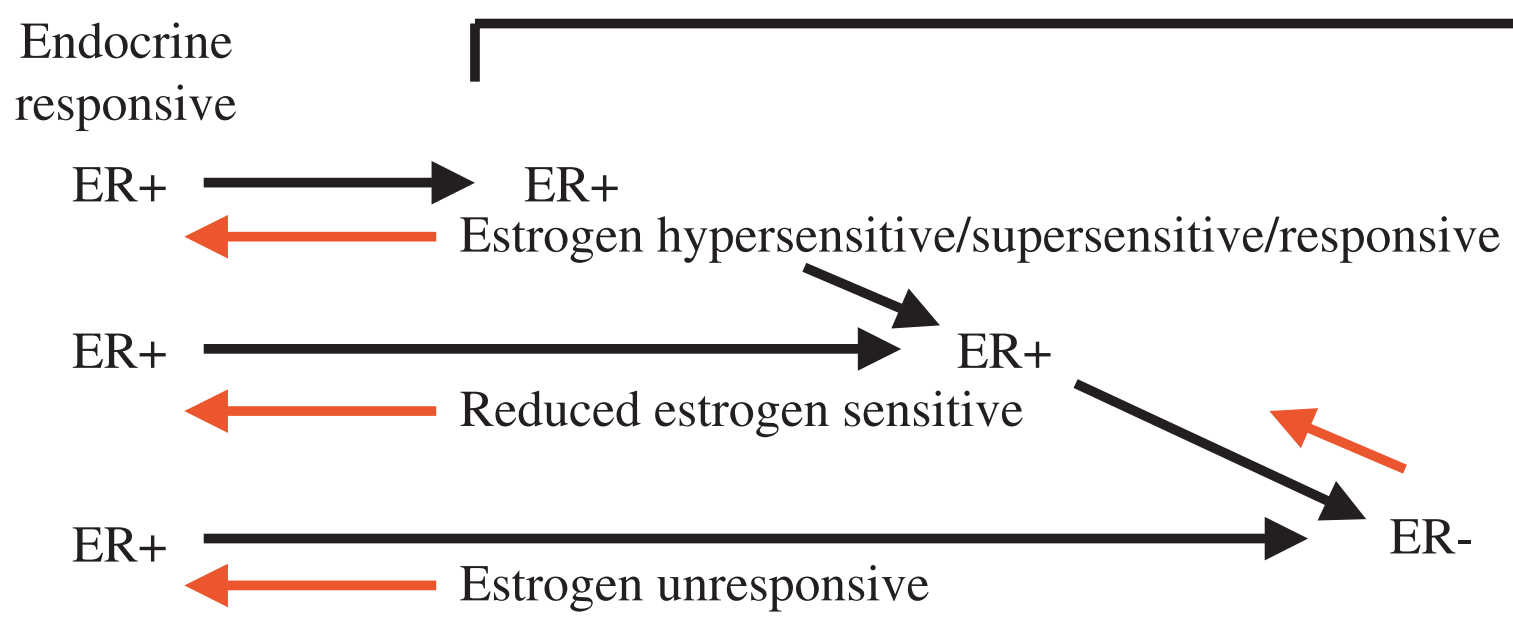

\section{Growth factor inhibitors}

Figure 4 Model of growth factor-driven mechanisms of resistance to estrogen withdrawal. The black lines represent the experimental influences associated with increased growth factor signaling in breast cancer cells, while the red lines represent the potential reversal of such events by growth factor inhibitors.

of an ER $\alpha$ - phenotype than either our tamoxifen or estrogen-withdrawn variants.

Such data raise the intriguing possibility that sustained growth factor signaling may underlie clinical $\mathrm{ER} \alpha$ negativity. About $30 \%$ of tumors are $\mathrm{ER} \alpha-$ at diagnosis, while a proportion of $\mathrm{ER} \alpha+$ tumors lack the receptor at the time of tamoxifen relapse in the adjuvant or metastatic setting. It is already established that the $\mathrm{ER} \alpha$ gene is silenced via $\mathrm{CpG}$ island methylation or histone deacetylation in a proportion of clinical breast cancers that are $\mathrm{ER} \alpha-$ on presentation (Parl 2003). Indeed, Yang et al. (2001) have shown that ER $\alpha$ negativity in the MDA-MB-231 and -435 cell lines can be partially reversed by the DNA methyl transferase 1 (DNMT1) inhibitor, aza-2-deoxycytidine (5-aza-dC) and by the histone deacetylase (HDAC) inhibitor, trichostatin (TSA), an event that restores some estrogen responsiveness from ERE reporter constructs and has obvious therapeutic implications for the future treatment of some $\mathrm{ER} \alpha-$ patients. However, if the above described association between chronic growth factor signaling and ER $\alpha$ loss occurs clinically, it may also be feasible to manipulate growth factor signaling to reinstate the ER $\alpha+$ phenotype in a proportion of $\mathrm{ER} \alpha-$ patients. In support of this association, growth factor signaling elements do appear most extreme in ER $\alpha$ - breast cancer, as evidenced by the established inverse association between $\mathrm{ER} \alpha$ and EGFR in clinical disease (Nicholson et al. 1994) and across multiple ER $\alpha$ - cell lines together with prominent ERK1/2 MAP kinase signaling (Biswas et al. 2000).

\section{Therapeutic implications for the future treatment of resistant breast cancer}

Many of the mechanisms that are emerging from laboratory studies, although complex, suggest that altered growth signaling cross-talking with $\mathrm{ER} \alpha$, as noted with antiestrogens, plays a central role in the development of acquired resistance to estrogen withdrawal. While detailed evaluation of these mechanisms is now clearly essential within clinical breast cancers from appropriate AI adjuvant trials and from examination of relapse material, model system data are already providing considerable rationale for designing anti-growth factor strategies, as well as improving anti-hormonal strategies, to treat or even prevent this disease state.

Given the concept of adaptive hypersensitivity that has arisen from the above models, one might expect that 
tamoxifen has only limited value in acquired resistance to estrogen deprivation since this drug could be perceived as an agonist (although surprisingly, there is model system data to suggest some efficacy may still be apparent; Long et al. 2002). However, it is feasible that continued optimization and improvement of estrogen deprivation strategies to further deplete estrogen levels may prove a fruitful avenue (Lonning 2001, Santen et al. 2004). Similarly, use of alternative AIs may be relevant for the development of resistance to initial therapy if they more potently reduce estrogen levels, since a lack of complete AI cross-resistance between the competitive inhibitors and inactivators has been reported (Lonning 2001). A unifying feature of all the acquired resistant models appears to be the value of near-maximally depleting ER $\alpha$ protein. Hence, the use of the pure antiestrogen, fulvestrant, to abrogate $E R \alpha /$ growth factor cross-talk may also be rational in acquired resistance. This agent is certainly effective following patient relapse on tamoxifen (Howell et al. 1996, Pritchard 2003, Santen et al. 2004), and preliminary data from acquired letrozole-resistant xenografts generated from aromatase-transfected $\mathrm{MCF}-7$ cells (MCF-7-Ca) also indicate fulvestrant sensitivity (Long et al. 2002). Finally, since model system data reveal toxicity of estrogens at higher concentrations, patients becoming resistant to estrogen deprivation may benefit from estrogens administered at pharmacological doses (Lonning 2001, Jordan et al. 2003). Clearly, further research is needed to define the optimal type and sequence of endocrine agents in this setting (Pritchard 2003).

Excitingly, the above described model system and emerging clinical data also provide considerable impetus to consider anti-growth-factor therapies on the development of resistance to estrogen deprivation or indeed other endocrine strategies. Although it is currently unclear whether the transitions shown in Fig. 4 are linked or distinct, and what the determinants are for their establishment, it is certainly encouraging that our armoury of inhibitors for growth factor signaling elements is exponentially increasing and that many do appear to be tolerated in cancer patients (Johnston et al. 2003, Jones et al. 2004). In the future, therefore, it is highly probable that such inhibitors will be clinically examined in breast cancer as a novel means of (i) treating endocrine resistant and insensitive states, (ii) preventing/delaying emergence of endocrine resistance and (iii) regenerating endocrine responsiveness in de novo-resistant or acquired-resistant disease.

The successful application of several signal transduction inhibitors in the Santen and Dowsett adaptive hypersensitivity models and parallel acquired antiestrogen-resistant sub-lines are highly encouraging with regards to possible therapeutic strategies. Targeting growth factor receptor expression/activation (e.g. EGFR, IGF-1R, HER2), elements interactive with $\mathrm{ER} \alpha$ (e.g. c-src kinase), or key downstream signaling elements (e.g. PI3K/AKT; Ras/Raf/MAP kinase) can clearly be growth inhibitory in these acquired-resistant models. Our own group has shown that blockade of EGFR signaling in tamoxifen- or fulvestrant-resistant cells with gefitinib inhibits cell growth, motility and invasiveness, with responses lasting up to 6 months before gefitinib resistance emerges (McClelland et al. 2001, Knowlden et al. 2003b, Nicholson et al. 2003, 2004). This compares favorably with the time taken to develop antiestrogen resistance in vitro ( $\sim 3$ months; Knowlden et al. 2003b). Within our new ER $\alpha+$ dependent model of resistance to estrogen deprivation, sensitivity to PI3K blockade is still apparent, despite the cells being largely refractory to EGFR, HER2 or IGF-1R inhibition. Furthermore, given that multiple signaling elements are clearly synergistic in determining adaptive resistance to estrogen deprivation in several of the models, a particularly exciting approach may be to logically combine anti-growth factor strategies (e.g. PI3K/Akt and MAP kinase inhibitor combination). Alternatively, 'dirty' agents that hit multiple signaling pathways, such as the Hsp90 inhibitor, 17allylamino-17-demethoxygeldanamycin (17AAG), known to promote degradation of multiple client proteins including tyrosine kinase receptors, signaling intermediates and steroid receptors and already demonstrated to be inhibitory in tamoxifen resistance, may prove valuable (Beliakoff et al. 2003).

There are also now several reports that logical combination of anti-hormonal and various anti-growthfactor strategies (e.g. anti-HER2, EGFR or Ras signaling) may be particularly powerful in preventing emergence of resistance, as well as restoring anti-hormone responsiveness in resistant cells (Wakeling et al. 2001, Johnston et al. 2003, Jones et al. 2004). Our own studies have demonstrated that when gefitinib is administered to antihormone-sensitive cells in combination with tamoxifen or fulvestrant (in anticipation of the development of EGFR signaling as a resistance mechanism), combination treatment promotes a much improved anti-proliferative and apoptotic effect than achieved with either drug alone (Gee et al. 2003, Nicholson et al. 2004). Indeed, apoptosis is so high using combination therapy that total cell kill is achieved and development of anti-hormone resistance is prevented (Gee et al. 2003). We hypothesize that since anti-hormones induce EGFR expression, early signaling from this receptor stimulates a survival pathway which reduces anti-hormone-mediated cell kill. Thus, the antihormone-treated cells, although initially growth inhibited, survive and eventually establish a resistant state driven by the EGFR pathway, an event abrogated by co-treatment with gefitinib (Gee et al. 2003). In a similar manner, we 
have recently described that co-targeting of EGFR and IGF-1R in our acquired tamoxifen-resistant cells is superior to inhibition of either pathway alone, where IGF-1R signaling clearly forms the survival and resistance mechanism recruited during treatment with gefitinib alone (Nicholson et al. 2004). Moreover, combination studies from Massarweh et al. (2002) have demonstrated that gefitinib delays resistance to estrogen deprivation and improves tamoxifen's anti-tumor activity in their de novo tamoxifen-resistant HER-2 transfected MCF-7 cells.

This article has also presented the available clinical and experimental data implicating growth factor signaling in $\mathrm{ER} \alpha+$ de novo resistance. Increased HER2/EGFR signaling is a feature of $\mathrm{ER} \alpha+$ de novo tamoxifen-resistant clinical material, phenotypic data implying that antigrowth factor strategies would be worthy of consideration in such tumors. Interestingly, emerging clinical data indicate that such $\mathrm{ER} \alpha+$ patients still respond to estrogen deprivation. The underlying growth mechanism for such tumors may therefore involve elevated EGFR/HER2 signaling cross-talking with $E R \alpha$, as described for acquired tamoxifen resistance. Addition of anti-HER2 or anti-EGFR strategies together with AIs could thus have potential to improve response and inhibit a proportion of such $\mathrm{ER} \alpha+$ de novo tamoxifen-resistant disease. Disappointingly, however, the recently published clinical trial of fulvestrant versus tamoxifen (Howell et al. 2004) shows that in the first-line setting tamoxifen is equivalent to fulvestrant, the data shedding doubt on the proposed ER $\alpha$ cross-talk with HER2/EGFR signaling in de novo resistance. There remains some concern as to whether an appropriate dose of fulvestrant was achieved in this trial, and certainly earlier studies with fulvestrant did not achieve complete ER $\alpha$ down-regulation, an event believed to discriminate its actions from SERMs. Nevertheless, continued study of appropriate de novo resistant models and further clinical trial material, notably AIresistant samples, clearly remains essential if we are fully to understand de novo resistance. Indeed, diverse cellular mechanisms outside the remit of this article, including aberrations in cell cycle components and tumor suppressor genes, have all been linked previously with de novo resistance, data suggesting that growth regulation of this state is not simply an extrapolation of acquired resistance mechanisms.

Finally, experimental growth factor challenge and transfection studies suggest that growth factor signaling elements aberrantly expressed may be able to promote de novo resistance under conditions of reduced $\mathrm{ER} \alpha$, and even in an $E R \alpha$-independent manner. Extreme or chronic, sustained growth factor signaling, arising during therapy or apparently de novo, can diminish ER $\alpha$ expression/ function, dislocate cells from ER $\alpha$ signaling promoting endocrine insensitivity, and generate ER negativity in models. Treatment of these insensitive states with appropriate anti-growth factors may again be possible, while such agents may also reverse this transition and re-instate the anti-hormone responsive phenotype. Excitingly, in vitro blockade of constitutive EGFR, HER2, or MAP kinase with MEK inhibitors or dominant negative constructs can re-instate $\mathrm{ER} \alpha$ expression in de novoresistant cells (Oh et al. 2001), and preliminary studies indicate that reversion of the ER $\alpha$ - phenotype and reinstatement of endocrine responsiveness is initiated in a proportion of advanced HER2+ breast cancer patients by use of herceptin to inhibit such growth factor signaling (Munzone et al. 2003).

This article, in total, establishes a proof of principle that blocking growth factor signaling cascades could be therapeutically effective (particularly in combination with anti-hormonal strategies) and it is certainly encouraging that preliminary data associated with the use of gefitinib in breast cancer patients resistant to tamoxifen are demonstrating clinical benefit, especially in ER $\alpha+$ acquired resistant disease (Robertson et al. 2003). We eagerly anticipate the results of various ongoing and proposed trials examining the efficacy of a spectrum of such agents in de novo and acquired endocrine resistance, in particular those aiming to treat or prevent resistance to estrogen deprivation.

\section{References}

Abdul-Wahab K, Corcoran D, Perachiotti A \& Darbre PD 1999 Overexpression of insulin-like growth factor II (IGFII) in ZR75-71 human breast cancer cells: higher threshold levels of receptor (IGFIR) are required for a proliferative response than for effects on specific gene expression. Cell Proliferation 32 271-287.

van Agthoven T, van Agthoven TL, Portengen H, Foekens JA \& Dorssers LC 1992 Ectopic expression of epidermal growth factor receptors induces hormone independence in ZR-75-71 human breast cancer cells. Cancer Research 52 5082-5088.

van Agthoven T, van Agthoven TL, Dekker A, Foekens JA \& Dorssers LC 1994 Induction of estrogen independence of ZR75-71 human breast cancer cells by epigenetic alterations. Molecular Endocrinology 8 1474-1483.

Akimoto T, Hunter NR, Buchmiller L, Mason K, Ang KK \& Milas L 1999 Inverse relationship between epidermal growth factor receptor expression and radiocurability of murine carcinomas. Clinical Cancer Research 5 2884-2890.

Arteaga CL, Carty-Dugger T, Moses HL, Hurd SD \& Pietenpol JA 1993 Transforming growth factor beta 1 can induce estrogen-independent tumorigenicity of human breast cancer cells in athymic mice. Cell Growth and Differentiation 4 193-201.

Atlas E, Cardillo M, Mehmi I, Zahedkargaran H, Tang C \& Lupu R 2003 Heregulin is sufficient for the promotion of 
tumorigenicity and metastasis of breast cancer cells in vivo. Molecular Cancer Research 1 165-175.

Bates NP \& Hurst HC 1997 An intron 1 enhancer element mediates estrogen-induced suppression of ERBB2 expression. Oncogene 15 473-481.

Baum M, Buzdar A, Cuzick J, Forbes J, Houghton J, Howell A \& Sahmoud T; The ATAC (Arimidex, Tamoxifen Alone or in Combination) Trialists' Group 2003 Anastrozole alone or in combination with tamoxifen versus tamoxifen alone for adjuvant treatment of postmenopausal women with earlystage breast cancer: results of the ATAC (Arimidex, Tamoxifen Alone or in Combination) trial efficacy and safety update analyses. Cancer 98 1802-1810.

Beliakoff J, Bagatell R, Paine-Murrieta G, Taylor CW, Lykkesfeldt AE \& Whitesell L 2003 Hormone-refractory breast cancer remains sensitive to the antitumor activity of heat shock protein 90 inhibitors. Clinical Cancer Research 9 4961-4971.

Benz CC, Scott GK, Sarup JC, Johnson RM, Tripathy D, Coronado E, Shepard HM \& Osborne CK 1993 Estrogendependent, tamoxifen-resistant tumorigenic growth of MCF-7 cells transfected with HER2/neu. Breast Cancer Research and Treatment 24 85-95.

van den Berg HW, Claffie D, Boylan M, McKillen J, Lynch M \& McKibben B 1996 Expression of receptors for epidermal growth factor and insulin-like growth factor I by ZR-75-71 human breast cancer cell variants is inversely related: the effect of steroid hormones on insulin-like growth factor I receptor expression. British Journal of Cancer 73 477-481.

Berstein LM, Zheng H, Yue W, Wang JP, Lykkesfeldt AE, Naftolin F, Harada H, Shanabrough M \& Santen RJ 2003 New approaches to the understanding of tamoxifen action and resistance. Endocrine-Related Cancer 10 267-277.

Berstein LM, Wang JP, Zheng H, Yue W, Conaway M \& Santen RJ 2004 Long-term exposure to tamoxifen induces hypersensitivity to estradiol. Clinical Cancer Research $\mathbf{1 0}$ 1530-1534.

Biswas DK, Cruz AP, Gansberger E \& Pardee AB 2000 Epidermal growth factor-induced nuclear factor kappa B activation: a major pathway of cell-cycle progression in estrogen-receptor negative breast cancer cells. PNAS 97 8542-8547.

Britton D, Hutcheson IR, Barrow D, Gee JMW \& Nicholson RI 2002 Increased estrogen receptor phosphorylation at serine 118 in tamoxifen resistant MCF-7 breast cancer cells. Biochemical Society Transactions 31 P114.

Britton D, Hutcheson IR, Barrow D, McClelland RA \& Nicholson RI 2003 Estrogen receptor phosphorylation in hormone sensitive and anti-hormone resistant breast cancer cells. Breast Cancer Research and Treatment 82 S61.

Bunone G, Briand PA, Miksicek RJ \& Picard D 1996 Activation of the unliganded estrogen receptor by EGF involves the MAP kinase pathway and direct phosphorylation. EMBO Journal 15 2174-2183.

Buzdar AU, Jonat W, Howell A \& Plourde PV 1997 ARIMIDEX: a potent and selective aromatase inhibitor for the treatment of advanced breast cancer. Journal of Steroid Biochemistry and Molecular Biology 61 145-149.
Campbell RA, Bhat-Nakshatri P, Patel NM, Constantinidou D, Ali S \& Nakshatri H 2001 Phosphatidylinositol 3-kinase/ AKT-mediated activation of estrogen receptor alpha: a new model for anti-estrogen resistance. Journal of Biological Chemistry 276 9817-9824.

Castoria G, Migliaccio A, Bilancio A, Di Domenico M, de Falco A, Lombardi M, Fiorentino R, Varricchio L, Barone MV \& Auricchio F 2001 PI3-kinase in concert with Src promotes the S-phase entry of oestradiol-stimulated MCF-7 cells. EMBO Journal 20 6050-6059.

Chan CM, Martin LA, Johnston SR, Ali S \& Dowsett M 2002 Molecular changes associated with the acquisition of estrogen hypersensitivity in MCF-7 breast cancer cells on long-term estrogen deprivation. Journal of Steroid Biochemistry and Molecular Biology 81 333-341.

Chen Z, Ke LD, Yuan XH \& Adler-Storthz K 2000 Correlation of cisplatin sensitivity with differential alteration of EGFR expression in head and neck cancer cells. Anticancer Research 20 899-902.

Chisamore MJ, Ahmed Y, Bentrem DJ, Jordan VC \& Tonetti DA 2001 Novel antitumor effect of estradiol in athymic mice injected with a T47D breast cancer cell line overexpressing protein kinase C alpha. Clinical Cancer Research 7 3156-3165.

Chrysogelos SA, Yarden RI, Lauber AH \& Murphy JM 1994 Mechanisms of EGF receptor regulation in breast cancer cells. Breast Cancer Research and Treatment 31 227-236.

Chung YL, Sheu ML, Yang SC, Lin CH \& Yen SH 2002 Resistance to tamoxifen-induced apoptosis is associated with direct interaction between Her2/neu and cell membrane estrogen receptor in breast cancer. International Journal of Cancer 97 306-312.

Ciardiello F \& Tortora G 2001 A novel approach in the treatment of cancer: targeting the epidermal growth factor receptor. Clinical Cancer Research 7 2958-2970.

Clarke R, Liu MC, Bouker KB, Gu Z, Lee RY, Zhu Y, Skaar TC, Gomez B, O'Brien K, Wang Y \& Hilakivi-Clarke LA 2003 Antiestrogen resistance in breast cancer and the role of estrogen receptor signaling. Oncogene 22 7316-7339.

Coutts AS \& Murphy LC 1998 Elevated mitogen-activated protein kinase activity in estrogen-nonresponsive human breast cancer cells. Cancer Research 58 4071-4074.

Daly RJ, King RJ \& Darbre PD 1990 Interaction of growth factors during progression towards steroid independence in $\mathrm{T}$ 47-D human breast cancer cells. Journal of Cell Biochemistry 43 199-211.

Daly RJ, Harris WH, Wang DY \& Darbre PD 1991 Autocrine production of insulin-like growth factor II using an inducible expression system results in reduced estrogen sensitivity of MCF-7 human breast cancer cells. Cell Growth and Differentiation 2 457-464.

Darbre PD \& Daly RJ 1990 Transition of human breast cancer cells from an estrogen responsive to unresponsive state. Journal of Steroid Biochemistry and Molecular Biology 37 753-763.

Demirpence E, Pons M, Balaguer P \& Gagne D 1992 Study of an antiestrogenic effect of retinoic acid in MCF-7 cells. Biochemical and Biophysical Research Communications 183 100-106. 
Dickstein BM, Wosikowski K \& Bates SE 1995 Increased resistance to cytotoxic agents in ZR75B human breast cancer cells transfected with epidermal growth factor receptor. Molecular and Cellular Endocrinology 110 205-211.

Donovan JC, Milic A \& Slingerland JM 2001 Constitutive MEK/ MAPK activation leads to p27(Kip1) deregulation and antiestrogen resistance in human breast cancer cells. Journal of Biological Chemistry 276 40888-40895.

Doucas V \& Yaniv M 1991 Functional interaction between estrogen receptor and proto-oncogene products c-Jun and cFos. Comptes Rendus des Seances de la Societe de Biologie et de ses Filiale 185 464-474.

Dowsett M, Harper-Wynne C, Boeddinghaus I, Salter J, Hills M, Dixon M, Ebbs S, Gui G, Sacks N \& Smith I 2001 HER-2 amplification impedes the antiproliferative effects of hormone therapy in estrogen receptor-positive primary breast cancer. Cancer Research 61 8452-8458.

Dowsett MC, Gutierrez S, Mohsin R, Schiff S, Detre S, Johnston \& Osborne CK 2003 Molecular changes in tamoxifen-relapsed breast cancer: relationship between ER, HER2 and P38MAP-kinase. Proceedings for the American Society of Clinical Oncology 223 (Abstract 7).

Dunn SE, Hardman RA, Kari FW \& Barrett JC 1997 Insulin-like growth factor I (IGF-I) alters drug sensitivity of HBL100 human breast cancer cells by inhibition of apoptosis induced by diverse anticancer drugs. Cancer Research 57 2687-2693.

El-Ashry D, Miller DL, Kharbanda S, Lippman ME \& Kern FG 1997 Constitutive Raf-1 kinase activity in breast cancer cells induces both estrogen-independent growth and apoptosis. Oncogene 15 423-435.

Elliott RL, Elliott MC, Wang F \& Head JF 1993 Breast carcinoma and the role of iron metabolism. A cytochemical, tissue culture, and ultrastructural study. Annals of the New York Academy of Sciences 698 159-166.

Ellis MJ, Coop A, Singh B, Mauriac L, Llombert-Cussac A, Janicke F, Miller WR, Evans DB, Dugan M, Brady C, Quebe-Fehling E \& Borgs M. 2001 Letrozole is more effective neoadjuvant endocrine therapy than tamoxifen for ErbB-1and/or ErbB-2-positive, estrogen receptor-positive primary breast cancer: evidence from a phase III randomized trial. Journal of Clinical Oncology 19 3808-3816.

de Fazio A, Chiew YE, McEvoy M, Watts CK \& Sutherland RL 1997 Antisense estrogen receptor RNA expression increases epidermal growth factor receptor gene expression in breast cancer cells. Cell Growth and Differentiation 8 903-911.

Fernandez P, Wilson C, Hoivik D \& Safe SH 1998 Altered phenotypic characteristics of T47d human breast cancer cells after prolonged growth in estrogen-deficient medium. Cell Biology International 22 623-633.

Figtree GA, Webb CM \& Collins P 2000 Tamoxifen acutely relaxes coronary arteries by an endothelium-, nitric oxide-, and estrogen receptor-dependent mechanism. Journal of Pharmacology and Experimental Therapeutics 295 519-523.

Font de Mora J \& Brown M 2000 AIB1 is a conduit for kinase-mediated growth factor signaling to the estrogen receptor. Molecular and Cellular Biology 20 5041-5047.

Fuqua SA, Wiltschke C, Zhang QX, Borg A, Castles CG, Friedrichs WE, Hopp T, Hilsenbeck S, Mohsin S, O'Connell P \& Allred DC 2000 A hypersensitive estrogen receptor-alpha mutation in premalignant breast lesions. Cancer Research $\mathbf{6 0}$ 4026-4029.

Gee JM \& Nicholson RI 2003 Expanding the therapeutic repertoire of epidermal growth factor receptor blockade: radiosensitization. Breast Cancer Research 5 126-129. Epub 2003 Feb 20.

Gee JM, Willsher PC, Kenny FS, Robertson JF, Pinder SE, Ellis IO \& Nicholson RI 1999 Endocrine response and resistance in breast cancer: a role for the transcription factor Fos. International Journal of Cancer 84 54-61.

Gee JM, Robertson JF, Ellis IO \& Nicholson RI 2001 Phosphorylation of ERK1/2 mitogen-activated protein kinase is associated with poor response to anti-hormonal therapy and decreased patient survival in clinical breast cancer. International Journal of Cancer 95 247-254.

Gee JMW, Madden TA, Robertson JFR \& Nicholson RI 2002 Clinical response and resistance to SERMS. In Endocrine Therapy in Breast Cancer, pp 155-190. Eds JFR Robertson, RI Nicholson \& DF Hayes. London: Martin Dunitz Ltd.

Gee JM, Harper ME, Hutcheson IR, Madden TA, Barrow D, Knowlden JM, McClelland RA, Jordan N, Wakeling AE \& Nicholson RI 2003 The antiepidermal growth factor receptor agent gefitinib (ZD1839/Iressa) improves antihormone response and prevents development of resistance in breast cancer in vitro. Endocrinology 144 5105-5117. Epub 2003 Aug 07.

Gooch JL, Van Den Berg CL \& Yee D 1999 Insulin-like growth factor (IGF)-I rescues breast cancer cells from chemotherapy induced cell death - proliferative and anti-apoptotic effects. Breast Cancer Research and Treatment 56 1-10.

Gottardis MM \& Jordan VC 1988 Development of tamoxifenstimulated growth of MCF-7 tumors in athymic mice after long-term antiestrogen administration. Cancer Research $\mathbf{4 8}$ 5183-5187.

Gross JM \& Yee D 2003 The type-1 insulin-like growth factor receptor tyrosine kinase and breast cancer: biology and therapeutic relevance. Cancer and Metastasis Review 22 327-336.

Guvakova MA \& Surmacz E 1997 Overexpressed IGF-I receptors reduce estrogen growth requirements, enhance survival, and promote E-cadherin-mediated cell-cell adhesion in human breast cancer cells. Experimental Cell Research 231 149-162.

Herman ME \& Katzenellenbogen BS 1994 Alterations in transforming growth factor-alpha and -beta production and cell responsiveness during the progression of MCF-7 human breast cancer cells to estrogen-autonomous growth. Cancer Research 54 5867-5874.

Howell A, DeFriend DJ, Robertson JF, Blamey RW, Anderson L, Anderson E, Sutcliffe FA \& Walton P 1996 Pharmacokinetics, pharmacological and anti-tumor effects of the specific anti-estrogen ICI 182,780 in women with advanced breast cancer. British Journal of Cancer $\mathbf{7 4}$ 300-308.

Howell A, Robertson JF, Abram P, Lichinitser MR, Elledge R, Bajetta E, Watanabe T, Morris C, Webster A, Dimery I \& Osborne CK 2004 Comparison of fulvestrant versus tamoxifen for the treatment of advanced breast cancer in postmenopausal women previously untreated with endocrine 
therapy: a multinational, double-blind, randomized trial. Journal of Clinical Oncology 22 1605-1613.

Hutcheson IR, Knowlden JM, Madden TA, Barrow D, Gee JM, Wakeling AE \& Nicholson RI 2003 Estrogen receptormediated modulation of the EGFR/MAPK pathway in tamoxifen-resistant MCF-7 cells. Breast Cancer Research and Treatment 81 81-93.

Hutcheson IR, Knowlden JM, Barrow D \& Nicholson RI 2004 IGF-1R/EGFR cross-talk in tamoxifen resistant MCF-7 breast cancer cells. AACR 2004 Proceedings 455189.

Jeng MH, Shupnik MA, Bender TP, Westin EH, Bandyopadhyay D, Kumar R, Masamura S \& Santen RJ 1998 Estrogen receptor expression and function in long-term estrogendeprived human breast cancer cells. Endocrinology 139 4164-4174.

Jeng MH, Yue W, Eischeid A, Wang JP \& Santen RJ 2000 Role of MAP kinase in the enhanced cell proliferation of long term estrogen deprived human breast cancer cells. Breast Cancer Research and Treatment 62 167-175.

Jensen J, Kitlen JW, Briand P, Labrie F \& Lykkesfeldt AE 2003 Effect of antiestrogens and aromatase inhibitor on basal growth of the human breast cancer cell line MCF-7 in serumfree medium. Journal of Steroid Biochemistry and Molecular Biology 84 469-478.

Jess TJ, Belham CM, Thomson FJ, Scott PH, Plevin RJ \& Gould GW 1996 Phosphatidylinositol 3'-kinase, but not p70 ribosomal $\mathrm{S} 6$ kinase, is involved in membrane protein recycling: wortmannin inhibits glucose transport and downregulates cell-surface transferrin receptor numbers independently of any effect on fluid-phase endocytosis in fibroblasts. Cellular Signaling 8 297-304.

Johnston SR \& Dowsett M 2003 Aromatase inhibitors for breast cancer: lessons from the laboratory. Nature Reviews Cancer $\mathbf{3}$ 821-831.

Johnston SR, Lu B, Scott GK, Kushner PJ, Smith IE, Dowsett M \& Benz CC 1999 Increased activator protein-1 DNA binding and c-Jun NH2-terminal kinase activity in human breast tumors with acquired tamoxifen resistance. Clinical Cancer Research 5 251-256.

Johnston SR, Head J, Pancholi S, Detre S, Martin LA, Smith IE \& Dowsett M 2003 Integration of signal transduction inhibitors with endocrine therapy: an approach to overcoming hormone resistance in breast cancer. Clinical Cancer Research 9 524S-532S.

Jones HE, Nicholson RI, Hutcheson IR, Knowlden JM, Harper ME, Jordan N, Hiscox SE, Barrow D \& Gee JMW 2004 Endocrine resistance in breast cancer: therapeutic intervention using signal transduction inhibitors. Advances in Breast Cancer $13-9$.

de Jong PC, Blankenstein MA, Nortier JW, Slee PH, van de Ven J, van Gorp JM, Elbers JR, Schipper ME, Blijham GH, Thijssen JH, Lu Q, Jelovac D \& Brodie AM 2003 The relationship between aromatase in primary breast tumors and response to treatment with aromatase inhibitors in advanced disease. Journal of Steroid Biochemistry and Molecular Biology 87 149-155.

Jordan VC, Osipo C, Schafer JM, Fox JE, Cheng D \& Liu H 2003 Changing role of the estrogen receptor in the life and death of breast cancer cells. Breast 12 432-441.
Jordan NJ, Gee JMW, Barrow D, Wakeling AE \& Nicholson RI 2004 Increased constitutive activity of PKB/Akt in tamoxifen resistant breast cancer MCF-7 cells. Breast Cancer Research and Treatment 87 167-180.

Kahlert S, Nuedling S, van Eickels M, Vetter H, Meyer R \& Grohe C 2000 Estrogen receptor alpha rapidly activates the IGF-I receptor pathway. Biological Chemistry 275 18447-18453.

Karnik PS, Kulkarni S, Liu XP, Budd GT \& Bukowski RM 1994 Estrogen receptor mutations in tamoxifen-resistant breast cancer. Cancer Research 54 349-353.

Katzenellenbogen BS, Kendra KL, Norman MJ \& Berthois Y 1987 Proliferation, hormonal responsiveness, and estrogen receptor content of MCF-7 human breast cancer cells grown in the short-term and long-term absence of estrogens. Cancer Research 47 4355-4360.

Knowlden JM, Hutcheson IR, Barrow D \& Nicholson RI 2003a IGF-1R and EGFR crosstalk in tamoxifen resistant breast cancer cells. Breast Cancer Research and Treatment 82 S171.

Knowlden JM, Hutcheson IR, Jones HE, Madden T, Gee JMW, Harper ME, Barrow D, Wakeling AE \& Nicholson RI 2003b Elevated levels of epidermal growth factor receptor/c-erbB2 heterodimers mediate an autocrine growth regulatory pathway in tamoxifen-resistant MCF-7 cells. Endocrinology 144 1032-1044.

Kurokawa H \& Arteaga CL 2003 ErbB (HER) receptors can abrogate antiestrogen action in human breast cancer by multiple signaling mechanisms. Clinical Cancer Research 9 511S-515S.

Li H \& Qian ZM 2002 Transferrin/transferrin receptor-mediated drug delivery. Medicinal Research Reviews 22 225-250.

Liu Y, El-Ashry D, Chen D, Ding IY \& Kern FG 1995 MCF-7 breast cancer cells overexpressing transfected c-erbB-2 have an in vitro growth advantage in estrogen-depleted conditions and reduced estrogen dependence and tamoxifen-sensitivity in vivo. Breast Cancer Research and Treatment 34 97-117.

Long B, McKibben BM, Lynch M \& van den Berg HW 1992 Changes in epidermal growth factor receptor expression and response to ligand associated with acquired tamoxifen resistance or estrogen independence in the ZR-75-71 human breast cancer cell line. British Journal of Cancer 65 865-869.

Long BJ, Jelovac D, Thiantanawat A \& Brodie AM 2002 The effect of second-line antiestrogen therapy on breast tumor growth after first-line treatment with the aromatase inhibitor letrozole: long-term studies using the intratumoral aromatase postmenopausal breast cancer model. Clinical Cancer Research 8 2378-2388.

Lonning PE 2001 Stepwise estrogen suppression manipulating the estrostat. Journal of Steroid Biochemistry and Molecular Biology 79 127-132.

Luftner D, Jung A, Schmid P, Geppert R, Kienle E, Wernecke KD \& Possinger K 2003 Takeda Adjuvant Breast Cancer Study with Leuprorelin Study Group. Upregulation of HER2/neu by ovarian ablation: results of a randomized trial comparing leuprorelin to CMF as adjuvant therapy in nodepositive breast cancer patients. Breast Cancer Research and Treatment 80 245-255.

McClelland RA, Barrow D, Madden TA, Dutkowski CM, Pamment J, Knowlden JM, Gee JM \& Nicholson RI 2001 
Enhanced epidermal growth factor receptor signaling in MCF7 breast cancer cells after long-term culture in the presence of the pure antiestrogen ICI 182,780 (Faslodex). Endocrinology 142 2776-2788.

McLeskey SW, Kurebayashi J, Honig SF, Zwiebel J, Lippman ME, Dickson RB \& Kern FG 1993 Fibroblast growth factor 4 transfection of MCF-7 cells produces cell lines that are tumorigenic and metastatic in ovariectomized or tamoxifentreated athymic nude mice. Cancer Research 53 2168-2177.

Martin MB, Garcia-Morales P, Stoica A, Solomon HB, Pierce M, Katz D, Zhang S, Danielsen M \& Saceda M 1995 Effects of 12-O-tetradecanoylphorbol-13-acetate on estrogen receptor activity in MCF-7 cells. Journal of Biological Chemistry 270 25244-25251.

Martin LA, Farmer I, Johnston SR, Ali S, Marshall C \& Dowsett M. 2003 Enhanced estrogen receptor (ER) alpha, ERBB2, and MAPK signal transduction pathways operate during the adaptation of MCF-7 cells to long term estrogen deprivation. Journal of Biological Chemistry 278 30458-30468. Epub 2003 May 29.

Masamura S, Santner SJ, Heitjan DF \& Santen RJ 1995 Estrogen deprivation causes estradiol hypersensitivity in human breast cancer cells. Journal of Clinical Endocrinology and Metabolism 80 2918-2925.

Massarweh S, Shou J, Mohsin SK, Ge M, Wakeling AE, Osborne CK \& Schiff R 2002 Inhibition of epidermal growth factor/ HER2 receptor signaling using ZD1839 ('Iressa') restores tamoxifen sensitivity and delays resistance to estrogen deprivation in HER2-overexpressing breast tumors. Proceedings for the American Society of Clinical Oncology 21 33 (Abstract).

Massarweh SA, Jiang S, Mohsin SK, DiPietro M, Wakeling AE, Osborne CK \& Schiff R 2003 Resistance to endocrine therapy in a xenograft model of HER-2 overexpressing breast cancer is accompanied by increased HER-2 but loss of IGF-1 receptor expression. Proceedings for the American Society of Clinical Oncology, 26th Annual Meeting, San Antonio, TX, USA. Abstract 1007.

Miller DL, El-Ashry D, Cheville AL, Liu Y, McLeskey SW \& Kern FG 1994 Emergence of MCF-7 cells overexpressing a transfected epidermal growth factor receptor (EGFR) under estrogen-depleted conditions: evidence for a role of EGFR in breast cancer growth and progression. Cell Growth and Differentiation 5 1263-1274.

Mouridsen H, Gershanovich M, Sun Y, Perez-Carrion R, Boni C, Monnier A, Apffelstaedt J, Smith R, Sleeboom HP, Janicke F, Pluzanska A, Dank M, Becquart D, Bapsy PP, Salminen E, Snyder R, Lassus M, Verbeek JA, Staffler B, Chaudri-Ross HA \& Dugan M 2001 Superior efficacy of letrozole versus tamoxifen as first-line therapy for postmenopausal women with advanced breast cancer: results of a phase III study of the International Letrozole Breast Cancer Group. Clinical Oncology 19 2596-2606.

Mueller H, Kueng W, Schoumacher F, Herzer S, \& Eppenberger U 1995 Selective regulation of steroid receptor expression in MCF-7 breast cancer cells by a novel member of the heregulin family. Biochemical and Biophysical Research Communications 217 1271-1278.
Munzone EF, Nole G, Renne A, Balduzzi G, Sanna L, Corsetto A \& Goldhirsch 2003 Reverting estrogen receptor (ER) negative phenotype in advanced breast cancer patients (pts) over-expressing HER2 after treatment with trastuzumab plus chemotherapy. Proceedings for the American Society of Clinical Oncology 22848 (Abstract 3409).

Murphy CS, Meisner LF, Wu SQ \& Jordan VC 1989 Short- and long-term estrogen deprivation of T47D human breast cancer cells in culture. European Journal of Cancer and Clinical Oncology 25 1777-1788.

Murphy CS, Pink JJ \& Jordan VC 1990 Characterization of a receptor-negative, hormone-nonresponsive clone derived from a T47D human breast cancer cell line kept under estrogen-free conditions. Cancer Research 50 7285-7292.

Nicholson RI \& Gee JM 2000 Estrogen and growth factor crosstalk and endocrine insensitivity and acquired resistance in breast cancer. British Journal of Cancer 82 501-513.

Nicholson RI, McClelland RA, Gee JM, Manning DL, Cannon P, Robertson JF, Ellis IO \& Blamey RW 1994 Epidermal growth factor receptor expression in breast cancer: association with response to endocrine therapy. Breast Cancer Research and Treatment 29 117-125.

Nicholson RI, Gee JM \& Harper ME $2001 a$ EGFR and cancer prognosis. European Journal of Cancer 37 (Suppl 4) S9-S15.

Nicholson RI, Hutcheson IR, Harper ME, Knowlden JM, Barrow D, McClelland RA, Jones HE, Wakeling AE \& Gee JM $2001 b$ Modulation of epidermal growth factor receptor in endocrine resistant, estrogen receptor-positive breast cancer. Endocrine-Related Cancer 8 175-182.

Nicholson RI, Gee JM, Knowlden J, McClelland R, Madden TA, Barrow D \& Hutcheson I 2003 The biology of antihormone failure in breast cancer. Breast Cancer Research and Treatment 80 (Suppl 1) S29-S34; discussion S35.

Nicholson RI, Hutcheson IR, Knowlden JM, Jones HE, Harper ME, Jordan N, Hiscox SE, Barrow D \& Gee JM 2004 Nonendocrine pathways and endocrine resistance: observations with antiestrogens and signal transduction inhibitors in combination. Clinical Cancer Research $\mathbf{1 0}$ 346S-354S.

Oh AS, Lorant LA, Holloway JN, Miller DL, Kern FG \& El-Ashry D 2001 Hyperactivation of MAPK induces loss of ERalpha expression in breast cancer cells. Molecular Endocrinology 15 1344-1359.

Osborne CK, Coronado E, Allred DC, Wiebe V \& DeGregorio M 1991 Acquired tamoxifen resistance: correlation with reduced breast tumor levels of tamoxifen and isomerization of trans-4-hydroxytamoxifen. Journal of the National Cancer Institute 83 1477-1482.

Osborne CK, Bardou V, Hopp TA, Chamness GC, Hilsenbeck SG, Fuqua SA, Wong J, Allred DC, Clark GM \& Schiff R 2003 Role of the estrogen receptor coactivator AIB1 (SRC-3) and HER-2/neu in tamoxifen resistance in breast cancer. Journal of the National Cancer Institute 95 353-361.

Parl FF 2003 Multiple mechanisms of estrogen receptor gene repression contribute to ER-negative breast cancer. Pharmacogenomics Journal 3 251-253.

Pelicci G, Lanfrancone L, Salcini AE, Romano A, Mele S, Grazia Borrello M, Segatto O, Di Fiore PP \& Pelicci PG 1995 
Constitutive phosphorylation of Shc proteins in human tumors. Oncogene 11 899-907.

Perez-Tenorio G, Stal O \& Southeast Sweden Breast Cancer Group 2002 Activation of AKT/PKB in breast cancer predicts a worse outcome among endocrine treated patients. British Journal of Cancer 86 540-545.

Pietras RJ, Arboleda J, Reese DM, Wongvipat N, Pegram MD, Ramos L, Gorman CM, Parker MG, Sliwkowski MX \& Slamon DJ 1995 HER-2 tyrosine kinase pathway targets estrogen receptor and promotes hormone-independent growth in human breast cancer cells. Oncogene 10 2435-2446.

Pink JJ \& Jordan VC 1996 Models of estrogen receptor regulation by estrogens and antiestrogens in breast cancer cell lines. Cancer Research 56 2321-2330.

Pink JJ, Bilimoria MM, Assikis J \& Jordan VC 1996 Irreversible loss of the estrogen receptor in T47D breast cancer cells following prolonged estrogen deprivation. British Journal of Cancer 74 1227-1236.

Pritchard KI 2003 Endocrine therapy of advanced disease: analysis and implications of the existing data. Clinical Cancer Research 9 460S-467S.

Razandi M, Pedram A, Park ST \& Levin ER 2002 Proximal events in signaling by plasma membrane estrogen receptors. Journal of Biology Chemistry 278 2701-2712.

Robertson JFR, Gutteridge E, Cheung KL, Owers R, Koehler M, Hamilton L, Gee J \& Nicholson RI 2003 Gefitinib (ZD1839) is active in acquired tamoxifen (TAM)-resistant estrogen receptor (ER)-positive and ER-negative breast cancer: results from a phase II study. Proceedings for the American Society of Clinical Oncology 227 (Abstract 23).

Russell KS \& Hung MC 1992 Transcriptional repression of the neu protooncogene by estrogen stimulated estrogen receptor. Cancer Research 52 6624-6629.

Saceda M, Knabbe C, Dickson RB, Lippman ME, Bronzert D, Lindsey RK, Gottardis MM \& Martin MB 1991 Posttranscriptional destabilization of estrogen receptor mRNA in MCF-7 cells by 12-O-tetradecanoylphorbol-13-acetate. Journal of Biological Chemistry 266 17809-17814.

Sachdev D \& Yee D 2001 The IGF system and breast cancer. Endocrine-Related Cancer 8 197-209.

Salomon DS, Brandt R, Ciardiello F \& Normanno N 1995 Epidermal growth factor-related peptides and their receptors in human malignancies. Critical Reviews in Oncology/ Haematology 19 183-232.

Santen RJ 2003 Inhibition of aromatase: insights from recent studies. Steroids 68 559-567.

Santen R, Jeng MH, Wang JP, Song R, Masamura S, McPherson R, Santner S, Yue W \& Shim WS 2001 Adaptive hypersensitivity to estradiol: potential mechanism for secondary hormonal responses in breast cancer patients. Journal of Steroid Biochemistry and Molecular Biology 79 $115-125$.

Santen RJ, Song RX, Zhang Z, Kumar R, Jeng MH, Masamura S, Yue W \& Berstein L 2003 Adaptive hypersensitivity to estrogen: mechanism for superiority of aromatase inhibitors over selective estrogen receptor modulators for breast cancer treatment and prevention. Endocrine-Related Cancer $\mathbf{1 0}$ 111-130.
Santen RJ, Song RX, Zhang Z, Yue W \& Kumar R 2004 Adaptive hypersensitivity to estrogen: mechanism for sequential responses to hormonal therapy in breast cancer. Clinical Cancer Research 10 337S-345S.

Schafer JM, Bentrem DJ, Takei H, Gajdos C, Badve S \& Jordan VC 2002 A mechanism of drug resistance to tamoxifen in breast cancer. Journal of Steroid Biochemistry and Molecular Biology 83 75-83.

Schiff R, Massarweh S, Shou J \& Osborne CK 2003 Breast cancer endocrine resistance: how growth factor signaling and estrogen receptor coregulators modulate response. Clinical Cancer Research 9 447S-454S.

Schiff R, Massarweh SA, Shou J, Bharwani L, Mohsin SK \& Osborne CK 2004 Cross-talk between estrogen receptor and growth factor pathways as a molecular target for overcoming endocrine resistance. Clinical Cancer Research $10331 \mathrm{~S}-336 \mathrm{~S}$.

Shim WS, Conaway M, Masamura S, Yue W, Wang JP, Kmar R \& Santen RJ 2000 Estradiol hypersensitivity and mitogenactivated protein kinase expression in long-term estrogen deprived human breast cancer cells in vivo. Endocrinology 141 396-405.

Smith LM, Wise SC, Hendricks DT, Sabichi AL, Bos T, Reddy P, Brown PH \& Birrer MJ 1999 cJun overexpression in MCF7 breast cancer cells produces a tumorigenic, invasive and hormone resistant phenotype. Oncogene 18 6063-6070.

Song RX \& Santen RJ 2003 Apoptotic action of estrogen. Apoptosis 8 55-60.

Song RX, Mor G, Naftolin F, McPherson RA, Song J, Zhang Z, Yue W, Wang J \& Santen RJ 2001 Effect of long-term estrogen deprivation on apoptotic responses of breast cancer cells to 17 beta-estradiol. Journal of the National Cancer Institute 93 1714-1723.

Song RX, Santen RJ, Kumar R, Adam L, Jeng MH, Masamura S \& Yue W 2002a Adaptive mechanisms induced by longterm estrogen deprivation in breast cancer cells. Molecular and Cellular Endocrinology 193 29-42.

Song RX, McPherson RA, Adam L, Bao Y, Shupnik M, Kumar R \& Santen RJ 2002b Linkage of rapid estrogen action to MAPK activation by ERalpha-Shc association and Shc pathway activation. Molecular Endocrinology 16 116-127.

Song RX, Barnes CJ, Zhang Z, Bao Y, Kumar R \& Santen RJ 2004 The role of Shc and insulin-like growth factor 1 receptor in mediating the translocation of estrogen receptor alpha to the plasma membrane. PNAS 101 2076-2081. Epub 2004 Feb 05.

Stephen RL, Shaw LE, Larsen C, Corcoran D \& Darbre PD 2001 Insulin-like growth factor receptor levels are regulated by cell density and by long term estrogen deprivation in MCF7 human breast cancer cells. Biological Chemistry 276 40080-40086. Epub 2001 Jul 16.

Stoica A, Saceda M, Fakhro A, Solomon HB, Fenster BD \& Martin MB 1997 The role of transforming growth factor-beta in the regulation of estrogen receptor expression in the MCF7 breast cancer cell line. Endocrinology 138 1498-1505.

Stoica A, Saceda M, Doraiswamy VL, Coleman C \& Martin MB $2000 a$ Regulation of estrogen receptor-alpha gene expression by epidermal growth factor. Journal of Endocrinology 165 371-378. 
Stoica A, Saceda M, Fakhro A, Joyner M \& Martin MB $2000 b$ Role of insulin-like growth factor-I in regulating estrogen receptor-alpha gene expression. Journal of Cellular Biochemistry 76 605-614.

Tang CK, Perez C, Grunt T, Waibel C, Cho C \& Lupu R 1996 Involvement of heregulin-beta2 in the acquisition of the hormone-independent phenotype of breast cancer cells. Cancer Research 56 3350-3358.

Tonetti DA, Chisamore MJ, Grdina W, Schurz H \& Jordan VC 2000 Stable transfection of protein kinase $\mathrm{C}$ alpha cDNA in hormone-dependent breast cancer cell lines. British Journal of Cancer 83 782-791.

Tsuda H 2001 Prognostic and predictive value of c-erbB-2 (HER$2 /$ neu) gene amplification in human breast cancer. Breast Cancer 8 38-44.

Tzukerman M, Zhang XK \& Pfahl M 1991 Inhibition of estrogen receptor activity by the tumor promoter $12-\mathrm{O}$ tetradeconylphorbol-13-acetate: a molecular analysis. Molecular Endocrinology 5 1983-1992.

Vickers PJ, Dickson RB, Shoemaker R \& Cowan KH 1988 A multidrug-resistant MCF-7 human breast cancer cell line which exhibits cross-resistance to antiestrogens and hormoneindependent tumor growth in vivo. Molecular Endocrinology 2 886-892.

Wakeling AE, Nicholson RI \& Gee JM 2001 Prospects for combining hormonal and nonhormonal growth factor inhibition. Clinical Cancer Research 7 (Suppl 12) 4350s-4355s; discussion $4411 \mathrm{~s}-4412 \mathrm{~s}$.

Wells A 1999 EGF receptor. International Journal of Biochemistry and Cellular Biology 31 637-643.

Welshons WV \& Jordan VC 1987 Adaptation of estrogendependent MCF-7 cells to low estrogen (phenol red-free) culture. European Journal of Cancer and Clinical Oncology 23 1935-1939.

Wilson MA \& Chrysogelos SA 2002 Identification and characterisation of a negative regulatory element within the epidermal growth factor receptor gene first intron in hormone-dependent breast cancer cells. Journal of Cellular Biochemistry 85 601-614.

Winer EP, Hudis C, Burstein HJ, Byrant J, Chlebowski RT, Ingle JN, Edge SB, Mamounas EP, Gelber R, Gralow J, Goldstein LJ, Pritchard KI, Braun S, Colbleigh MA, Langer AS, Perotti J, Powles TJ, Whelan TJ \& Browman GP 2003 ASCO technology assessment working group update: use of aromatase inhibitors in the adjuvant setting. Journal of Clinical Oncology 21 2597-2599.

Wong ZW \& Ellis MJ 2004 First-line endocrine treatment of breast cancer: aromatase inhibitor or antiestrogen? British Journal of Cancer 90 20-25.

Yang X, Phillips DL, Ferguson AT, Nelson WG, Herman JG \& Davidson NE 2001 Synergistic activation of functional estrogen receptor (ER)-alpha by DNA methyltransferase and histone deacetylase inhibition in human ER-alpha-negative breast cancer cells. Cancer Research 61 7025-7029.

Yarden RI, Wilson MA \& Chrysogelos SA 2001 Estrogen suppression of EGFR expression in breast cancer cells: a possible mechanism to modulate growth. Journal of Cellular Biochemistry 81 232-246.

Yu Y \& Feig LA 2002 Involvement of R-Ras and Ral GTPases in estrogen-independent proliferation of breast cancer cells. Oncogene 21 7557-7568.

Yue W, Berstein LM, Wang JP, Clark GM, Hamilton CJ, Demers LM \& Santen RJ 2001 The potential role of estrogen in aromatase regulation in the breast. Journal of Steroid Biochemistry and Molecular Biology 79 157-164.

Yue W, Wang JP, Conaway M, Masamura S, Li Y \& Santen RJ 2002 Activation of the MAPK pathway enhances sensitivity of MCF-7 breast cancer cells to the mitogenic effect of estradiol. Endocrinology 143 3221-3229.

Yue W, Wang JP, Conaway MR, Li Y \& Santen RJ 2003 Adaptive hypersensitivity following long-term estrogen deprivation: involvement of multiple signal pathways. Journal of Steroid Biochemistry and Molecular Biology 86 265-274. 